\title{
From magmatic to hydrothermal Sn-Li-(Nb-Ta-W) mineralization: The Argemela area (central Portugal)
}

\author{
Julie Anne-Sophie Michaud, Charles Gumiaux, Michel Pichavant, Eric Gloaguen, Eric Marcoux \\ Université d'Orléans/CNRS/BRGM/ISTO, UMR 7327, F-45071 Orléans, France
}

\section{A R T I C LE IN F O}

\section{Keywords}

Argemela

Variscan

Sn-Li-(Nb-Ta-W) mineralization

Magmatic

Hydrothermal

Portugal

\begin{abstract}
A B S T R A C T
The Argemela mineralized area (AMA), central Portugal, exhibits a nearly continuous magmatic to hydrothermal ore-forming sequence typical of Variscan granite-related rare metal deposits. Disseminated and vein-type mineralization are distributed in two systems, the Argemela Mine (AM) and the Cabeço da Argemela (CA). Disseminated mineralization includes montebrasite, cassiterite and columbite-tantalite dispersed in rare metal granites. Vein-type mineralization occurs both in granites and country rocks. The CA system exposes three generations of intragranitic veins with montebrasite in the two earliest and montebrasite, wolframite, cassiterite and columbite-tantalite in the latest. Country rock veins include a swarm of cassiterite and montebrasite veins (AM) and rare isolated wolframite veins (CA). Disseminated cassiterites are enriched in $\mathrm{Ta}_{2} \mathrm{O}_{5}$ and $\mathrm{Nb}_{2} \mathrm{O}_{5}$ compared to vein cassiterites. Disseminated columbite-tantalites evolve toward Mn- and Ta-rich chemistries that contrast with the more Fe- and Nb-rich compositions in intragranitic veins. In the CA system, both intragranitic and country rock veins crystallize early Mn-rich wolframites followed by late more Fe-rich compositions associated with Nb-, Ta-poor cassiterite, the later replaced by stannite. Field relations, structural, mineralogical and geochemical data suggest that the disseminated and vein-type mineralization are expressions of a continuous metallogenic evolution initiated at the magmatic stage, pursued during the magmatic-hydrothermal transition and ended with hydrothermal circulations in country rock. The two mineralized systems share similarities, but they also show major differences. Structural analysis demonstrates that the intragranitic veins in the CA and the country rock veins in the AM were emplaced under the same tectonic regime. Therefore, the two systems are variants of the same local metallogenic evolution. Sn and W show markedly contrasted behaviors. Both have a magmatic source but only Sn reaches concentrations leading to saturation of the melt with cassiterite. $\mathrm{W}$ is deposited later and preferentially to Sn in intragranitic veins. At the hydrothermal stage, cassiterite and wolframite deposition are disconnected and, overall, wolframite occurs only in minor amounts. The metallogenic model proposed for the AMA emphasizes magmatic rare metal concentration processes, exsolution of magmatic fluids and selective deposition of metals during the magmatic-hydrothermal and later hydrothermal stages. The Sn-Li-(Nb-Ta)-dominated, and W-poor signature of the AMA makes it similar to LCT pegmatites of the Central Iberian Zone but is distinctive from the world class W-(Sn-Cu) Panasqueira deposit nearby.
\end{abstract}

\section{Introduction}

Extending from Iberia to the Bohemian massif, the Western Europe Variscan belt is a renowned, well-defined metallogenic province (Marignac and Cuney 1999; Romer and Kroner 2016). Mineralization occurring as $\mathrm{Sn}$-, W-, Li-, Nb- and Ta-bearing minerals is usually spatially related to granitic intrusions and their volcanic counterparts (Cuney et al. 1990; Cuney et al. 1992; Černý et al. 2005; Štemprok and Blecha 2015; Harlaux et al. 2017). Ore-bearing minerals are found disseminated in evolved granitic stocks (e.g., Beauvoir: Cuney et al. 1992; Raimbault et al. 1995; review and definition of rare metal granites in Linnen and Cuney, 2005; Černý et al., 2005), intragranitic or country rock quartz veins and stockworks (e.g.,
Panasqueira, Portugal: Kelly and Rye 1979; Neiva 2008; Hemerdon, Cornwall: Cameron 1951; LeBoutillier 2002; Logrosán, Spain: Chicharro et al. 2016; French Massif Central: Béziat et al. 1980; Demange et al. 1988; Lerouge et al. 2000; Harlaux et al. 2018), greisens (e.g., Cínovec, Czech Republic: Breiter et al. 2017), skarns (e.g., Los Santos, Spain: Tornos et al., 2008) and in breccia pipes (e.g., Puy Les Vignes, France: Harlaux et al., 2015), among others.

From a genetic perspective, rare-metal concentration, transport and deposition result from a combination of magmatic and hydrothermal processes (Cuney et al., 1990; Breiter et al., 2017; Lecumberri-Sanchez et al., 2017; Harlaux et al., 2018; Michaud and Pichavant, 2019, Michaud, 2019). The imprint of magmatic processes is particularly clear in disseminated mineralization hosted in rare-metal 
granites (e.g., Linnen and Cuney, 2005; Černý et al. 2005; Breiter et al. 2007). However, most deposits of the Variscan belt hardly exhibit the early stages of the metallogenic evolution, the magmatic imprint being obliterated by hydrothermal systems which quasi-systematically develop within and around granite bodies. Evaluating the relative importance of magmatic and hydrothermal events in the sequence of ore-forming processes remains, though, critical (Taylor and Hosking 1970; Kelly and Rye 1979; Cuney et al. 1992; Smith et al 1996; Rickers et al 2006; Lecumberri-Sanchez et al 2017; Breiter et al. 2017). Among the various metals concentrated in Variscan granite-related mineralization, $\mathrm{Sn}$ and W show contrasted behaviors and thus constitute very good markers to decipher imprints of magmatic vs hydrothermal processes. Indeed, cassiterite is present both as disseminated and in vein-type mineralization while wolframite crystallization is almost exclusively associated with hydrothermal deposition stages (Che et al. 2013). While evidence for magmatic cassiterite exists (Neiva, 1996; Černý et al. 2005; Breiter et al., 2007), there is still uncertainty as to whether $\mathrm{W}$ can be concentrated as the result of magmatic processes (Heinrich 1990; Lehmann 1990; Štemprok 1995; Marignac and Cathelineau 2009; Harlaux et al. 2018). This stresses the need for studies of mineralized districts allowing to continuously track the behavior of metals during the whole magmatic to hydrothermal evolution, using for instance Sn-W.

The Argemela mineralized area (AMA, Central Portugal) exhibits several rare element mineralized components (Michaud, 2019). In this paper, each component of the area is described combining field, structural, mineralogical and geochemical studies. Different mineralizing events are identified and demonstrated to be part of a nearly continuous metallogenic evolution initiated at the magmatic stage, pursued during the magmatic-hydrothermal transition and ended at the hydrothermal stage. The Sn and W behavior is detailed and a metallogenic model constructed for the AMA as a whole. Results stress the importance of magmatic processes and demonstrate significant differences between the AMA and the world class Panasqueira deposit nearby and other Variscan $\mathrm{W}$ deposits.

\section{Geological setting}

The Argemela mineralized area is part of the Central Iberian Zone (CIZ) Sn-W metallogenic province, in the southwestern part of the
Variscan belt. The Western Europe Variscan belt results from the continental collision between Gondwana, Laurussia and some intercalated satellite microcontinents during Paleozoic times (Autran et Cogné 1980; Bard et al. 1980; Matte 1986; Faure et al. 1997). During the Carboniferous, crustal thickening induced partial melting marked by migmatites in the lower crust and voluminous peraluminous granitic intrusions in the upper crust; syn to post orogenic extension of the softened crust then occured (e.g. Faure 1995). Rare-metal enriched granites and $\mathrm{Sn}-\mathrm{W}$ ore deposits are generally related to this late orogenic stage (Marignac and Cuney 1999; Cuney et al., 2002) and their origin has been proposed to be linked with granulite metamorphism (Cuney and Barbey 2014).

The Argemela area is located in the southwestern part of the CIZ which consists in autochtonous Gondwanian units and is characterized by numerous granitic plutons intruded into Neoproterozoic to Cambrian metasediments (namely the Schists and Greywackes Complex, SGC) and into the Ordovician Armorican quartzite formation (Fig. 1). This region has undergone continuous deformation during the Variscan tectonic evolution (see Ábalos et al., 2002; Dias and Ribeiro, 1995; Díez Balda et al., 1990; Martínez Poyatos et al., 2001; Ribeiro et al., 1990b, 1990a). The first deformation event (e.g., D1; Dias and Ribeiro 1995) is a compression, Devonian in age, which led to narrow NW-SE trending subvertical folds. Folding is pervasive and folds envelope is horizontal over the entire domain which highlights coaxial deformation regime with subhorizontal NE trending shortening, normal to the main belt trending (Díez Balda and Vegas, 1990). The Ordovician Armorican quartzites outline synclines while anticlines correspond to pre-Ordovician series (Fig. 1). The second main deformation stage, Carboniferous in age (e.g., D3; Dias and Ribeiro 1995), corresponds to the formation of vertical ENE-WSW sinistral strike slip shear zones and of NW-SE (not shown on Fig. 1) to NNW-SSE ones (Pereira et al. 1993), consistent with a large-scale $\sim$ NE-SW subhorizontal shortening. While the principal maximum shortening axis remains stable from D1, in a continuous deformation setting, the principal stretching shifted from vertical to horizontal. Finally, the latest structures (Permian; Dias and Ribeiro 1995) correspond to a conjugate system of NE-SW to NNE-SSW sinistral (Fig. 1) and NW-SE dextral strike-slips faults associated to a N-S/NNW-SSE shortening direction (Pereira et al 1993). Several NE-SW faults were reactivated as thrust

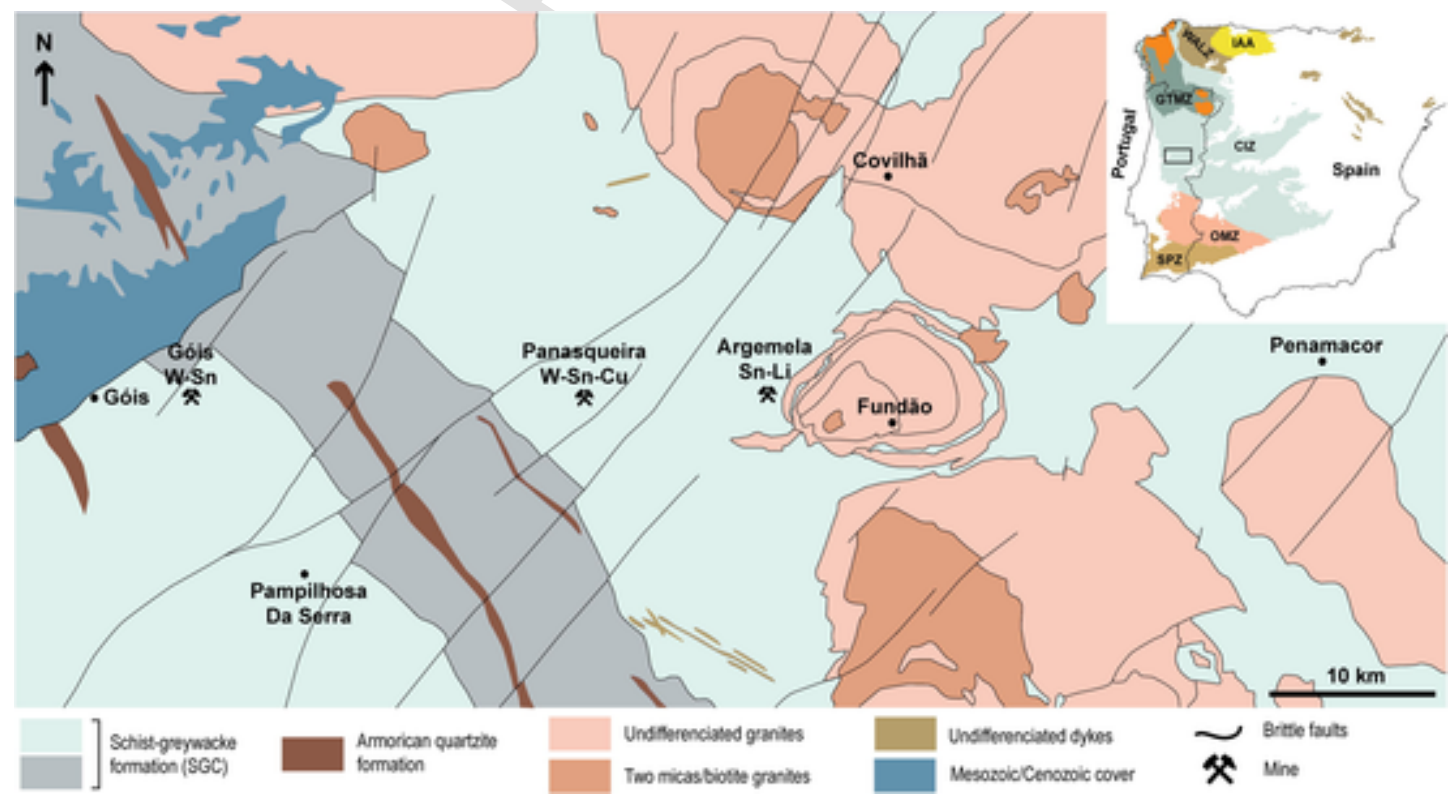

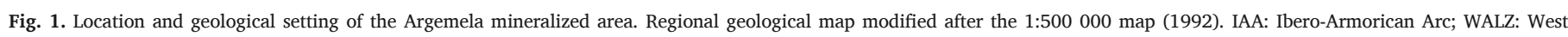
Asturian-Leonese Zone; GMTZ: Galicia-Tràs-os-Montes; CIZ: Central Iberian Zone; OMZ: Ossa Morena Zone; SPZ: South-Portuguese Zone. 
faults by compressional tectonism during the Miocene leading to local uplift and the erosion of the Meso-Cenozoic cover (e.g., Ribeiro et al., 1990a,b).

As part of the Gois-Panasqueira-Argemela-Segura mineralized axis (Inverno and Ribeiro 1980, Fig. 1), the AMA developed in the low-grade Beira schists (belonging to the SGC). It lies about $13 \mathrm{~km}$ east from the Panasqueira world class tungsten mine (Fig. 1) in the western aureole of the composite Fundão pluton (monzogranite to two micas granite; Ferreira et al. 1985). The AMA developed in a regional-scale pressure shadow marked by the deflection of the S1 cleavage around Fundão (Michaud, 2019). Besides, the area is affected by several local scale scattered $\sim$ N170-NS dextral shear corridors consistent with the
NE striking horizontal principal shortening. The AMA is composed of two distinct mineralized systems being located $\sim 200 \mathrm{~m}$ apart (Fig. 2): the Argemela Mine system (AM) and the Cabeço da Argemela system (CA). Following Inverno and Ribeiro (1980) among others, the AM system is made of a swarm of Sn-Li-bearing veins emplaced near a hidden granitic apophyse, at depth. Inferred resources of the AM system is $11.1 \mathrm{Mt}$ of ore grading $0.21 \% \mathrm{Li}$ and $0.15 \% \mathrm{Sn}$ (Consultores, 2017). The CA is mainly made of the Argemela granite and of a few veins (Fig. 2). The granite, a representative example of peraluminous high phosphorus rare-metal granite (RMG; Charoy and Noronha 1996, 1999 ), is very well exposed in a $120 \times 80 \mathrm{~m}$ operating quarry at the top of the Argemela hill. It is noteworthy that two distinct geochrono-

Argemela Mine countryrock veins
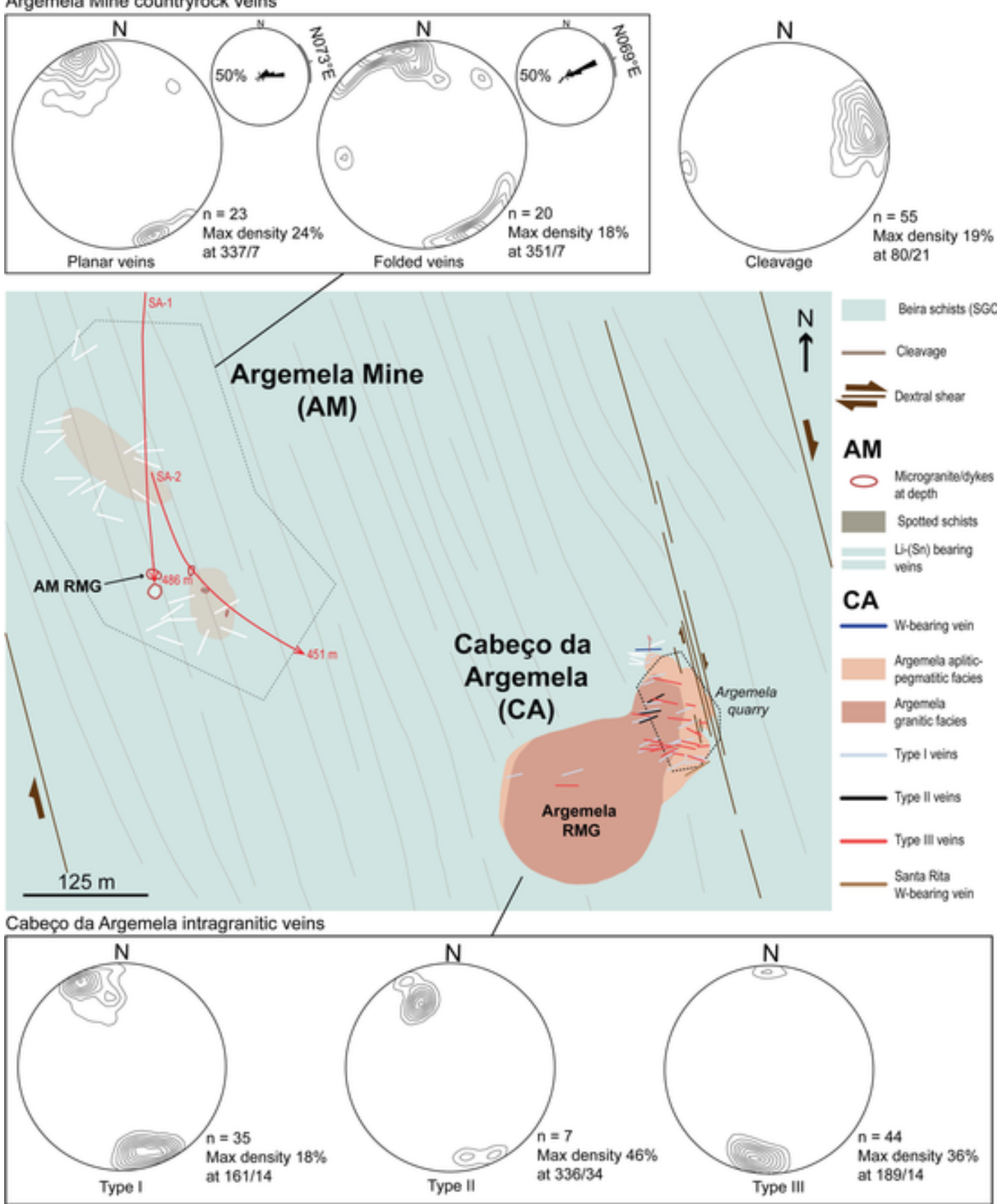

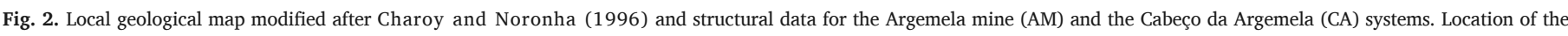

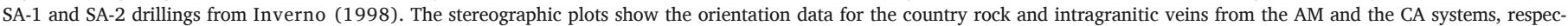
tively, and the orientation data for the S1 cleavage. 
logical studies gave two different estimation dates for the granite emplacement with $303 \pm 6 \mathrm{Ma}$ (K-Ar muscovite, Noronha et al., 2013) and $326 \pm 3 \mathrm{Ma}(\mathrm{U} / \mathrm{Pb}$ columbite-tantalite, Melleton and Gloaguen, 2015). Almost elliptical in map view, the Argemela RMG is affected by one of the $\sim$ N170-NS striking dextral zones mentioned above (Fig. 2, Michaud, 2019).

\section{Methods and analytical techniques}

Field work in the AMA lasted for a total of one and a half month and was completed by studies of two cores (SA-1 and SA-2) stored at the Portuguese Geological Survey (LNEG, Porto). These cores were drilled during the late 70 's as part of an exploration campaign targeted on the AM Sn-Li vein system.

A total of 118 rock samples were collected from in-situ outcrops and 28 more from the cores. These were used to prepare thin and polished sections. Preliminary petrographic and textural observations were made using a petrographic microscope. Whole rock analyses were performed at the Service d'Analyse des Roches et des Minéraux (SARM, Nancy). Detection limits are given in Table 1. Backscattered electron (BSE) images were obtained using a Merlin compact ZEISS Microscope equipped with a Bruker EDS detector and working under an acceleration voltage of $15 \mathrm{kV}$. All analyses of ore minerals were conducted at the Institut des Sciences de la Terre d'Orléans (ISTO, France). Spot analyses for major and minor elements were obtained using a CAMECA SX Five microprobe operated under an acceleration voltage and a beam current of $20 \mathrm{kV}$ and 40nA respectively. Standards included $\mathrm{Al}_{2} \mathrm{O}_{3}(\mathrm{Al} K \alpha)$, apatite (PKo), topaz ( $\mathrm{F} K \alpha)$, cassiterite $\mathrm{SnO}_{2}(\mathrm{Sn} L \alpha)$, hematite $\mathrm{Fe}_{2} \mathrm{O}_{3}(\mathrm{Fe} K \alpha)$, synthetic $\mathrm{MnTiO}_{3}(\mathrm{MnK} \alpha$ and $\mathrm{Ti} K \alpha)$ and pure $\mathrm{Nb}(\mathrm{Nb} L \alpha)$, Ta $(\mathrm{Ta} L \alpha)$ and $\mathrm{W}(\mathrm{W} L \alpha)$ metals. A homogeneous cassiterite crystal was used as a secondary standard and analytical errors (i.e., standard deviations calculated on 25 analyses) are: $1 \mathrm{wt} \%\left(\mathrm{SnO}_{2}\right), 0.3 \mathrm{wt} \%\left(\mathrm{Nb}_{2} \mathrm{O}_{5}, \mathrm{WO}_{3}\right), 0.2 \mathrm{wt} \%$ $\left(\mathrm{Ta}_{2} \mathrm{O}_{5}, \mathrm{TiO}_{2}\right), 0.1 \mathrm{wt} \%(\mathrm{FeO})$, and $0.01 \mathrm{wt} \%(\mathrm{MnO})$. For columbite-tantalite, standard deviations were calculated on 11 analyses of homogeneous CT I and are as follows: $0.2 \mathrm{wt} \%$ for $\mathrm{TiO}_{2}, 0.8 \mathrm{wt} \%$ for $\mathrm{MnO}$, $0.6 \mathrm{wt} \%$ for $\mathrm{FeO}, 2.1 \mathrm{wt} \%$ for $\mathrm{Nb}_{2} \mathrm{O}_{5}, 0.8 \mathrm{wt} \%$ for $\mathrm{SnO}_{2}$ and $2.5 \mathrm{wt} \%$ for $\mathrm{WO}_{3}$, and for montebrasite on 6 analyses: $0.7 \mathrm{wt} \%\left(\mathrm{Al}_{2} \mathrm{O}_{3}\right), 1.2 \mathrm{wt} \%$ $\left(\mathrm{P}_{2} \mathrm{O}_{5}\right)$ and $0.3 \mathrm{wt} \%(\mathrm{~F})$.

Field and petrographic observations were supplemented by a structural analysis based on (i) detailed mapping of structures, veins and outline of the Argemela intrusion, (ii) statistical analysis of vein orientations and geometry and (iii) characterization of vein finite strain.

\section{Results: petro-structural analysis}

\subsection{The Argemela area: A dual mineralized system}

Two types of mineralization can be recognized in the AMA: (i) Li-Sn-Nb-Ta disseminated mineralization spread in rare metal granite intrusions and (ii) Li-Sn-Nb-Ta-W vein-type mineralization occurring both in granite and surrounding rocks. The two types occur both in the AM and the CA systems (Fig. 2). Mineralization in the AM comprises: (1) a network of previously mined Sn- and Li-bearing veins emplaced within the Beira schists and (2) granitic rocks (AM RMG) only encountered at the tip of the SA-1 drill core (from 455 to $486 \mathrm{~m}$ ). The CA mineralized system consists of: (1) individual $\mathrm{Li}$ and W-bearing veins also emplaced within the Beira schists, (2) The Argemela rare-metal granite (Argemela RMG) which forms an intrusion of limited cartographic extension presently exploited for quartz and feldspar (Felmica Minerais Industriais, SA) devoted to ceramic industry and (3) intragranitic Li-Sn-Nb-Ta-W veins which includes the Santa Rita W-bearing vein previously hand-exploited.
Table 1

Representative bulk rock composition of granitic rocks.

\begin{tabular}{|c|c|c|c|c|c|}
\hline System & $\mathrm{CA}$ & & $\mathrm{AM}$ & & $\begin{array}{l}\text { Detection } \\
\text { limits }\end{array}$ \\
\hline Type & \multicolumn{2}{|c|}{ Argemela RMG } & $\begin{array}{l}\text { AM } \\
\text { RMG }\end{array}$ & $\begin{array}{l}\text { AM } \\
\text { Dyke }\end{array}$ & \multirow[b]{2}{*}{ wt $\%$} \\
\hline $\begin{array}{l}\text { Major elements } \\
\text { (wt\%) }\end{array}$ & A4 & $\begin{array}{l}\text { ARGE } \\
4^{*}\end{array}$ & $\mathrm{C} 25$ & $\mathrm{C} 21$ & \\
\hline $\mathrm{SiO}_{2}$ & 69.21 & 69.09 & 72.53 & 69.78 & 0.05 \\
\hline $\mathrm{TiO}_{2}$ & - & - & bdl & bdl & 0.10 \\
\hline $\mathrm{Al}_{2} \mathrm{O}_{3}$ & 18.19 & 17.85 & 16.36 & 18.61 & 0.06 \\
\hline $\mathrm{FeO}$ & 0.32 & 0.61 & 0.39 & 0.50 & 0.03 \\
\hline $\mathrm{MnO}$ & 0.02 & 0.06 & bdl & bdl & 0.01 \\
\hline $\mathrm{MgO}$ & - & - & 0.10 & 0.09 & 0.04 \\
\hline $\mathrm{CaO}$ & - & 0.07 & 0.46 & 0.24 & 0.10 \\
\hline $\mathrm{Na}_{2} \mathrm{O}$ & 5.27 & 5.69 & 7.14 & 8.00 & 0.03 \\
\hline $\mathrm{K}_{2} \mathrm{O}$ & 3.81 & 2.74 & 1.26 & 1.55 & 0.08 \\
\hline $\mathrm{P}_{2} \mathrm{O}_{5}$ & 1.74 & 1.37 & 0.44 & 0.32 & 0.20 \\
\hline $\mathrm{F}$ & 0.29 & 1.11 & 0.13 & 0.20 & \multirow{6}{*}{ ppm } \\
\hline LOI & 1.45 & 1.80 & 1.34 & 1.16 & \\
\hline Total & 100.01 & 99.63 & 100.00 & 100.26 & \\
\hline \multicolumn{5}{|c|}{ Trace elements (ppm) } & \\
\hline B & NA & NA & 21.0 & 21.3 & \\
\hline $\mathrm{Li}$ & 1731 & 4395 & 105 & 268 & \\
\hline As & 4.86 & NA & 4.33 & 163.99 & 0.200 \\
\hline $\mathrm{Ba}$ & 9.70 & $<5$ & 31.20 & 45.89 & 2.000 \\
\hline $\mathrm{Be}$ & 27.50 & 92.00 & 44.71 & 13.59 & 0.090 \\
\hline $\mathrm{Ce}$ & 0.22 & 0.318 & 0.10 & 0.07 & 0.020 \\
\hline Cs & 32.40 & 300 & 22.11 & 24.04 & 0.020 \\
\hline $\mathrm{Cu}$ & 6.90 & NA & 21.09 & 42.77 & 6.000 \\
\hline $\mathrm{Eu}$ & 0.01 & 0.0046 & 0.01 & 0.01 & 0.002 \\
\hline Ga & 36.90 & 31.00 & 28.95 & 34.92 & 0.015 \\
\hline $\mathrm{Ge}$ & 4.28 & NA & 4.88 & 5.03 & 0.050 \\
\hline $\mathrm{Hf}$ & 2.65 & 2.30 & 2.70 & 3.11 & 0.030 \\
\hline $\mathrm{La}$ & 0.12 & 0.182 & 0.08 & 0.07 & 0.040 \\
\hline $\mathrm{Lu}$ & - & 0.0042 & - & - & 0.001 \\
\hline $\mathrm{Nb}$ & 62.00 & 67.00 & 76.19 & 27.75 & 0.020 \\
\hline $\mathrm{Pb}$ & 27.00 & NA & 7.78 & 10.46 & 0.350 \\
\hline $\mathrm{Rb}$ & 1147 & 2130 & 458 & 551 & 0.200 \\
\hline $\mathrm{Sb}$ & 0.12 & NA & 0.16 & 0.19 & 0.050 \\
\hline Sn & 871 & 635 & 586 & 104 & 2.000 \\
\hline $\mathrm{Sr}$ & 12.70 & $<5$ & 29.27 & 97.25 & 0.700 \\
\hline $\mathrm{Ta}$ & 61.80 & 66.00 & 83.80 & 21.93 & 0.002 \\
\hline Th & 0.57 & 0.01 & 0.92 & 0.53 & 0.010 \\
\hline $\mathrm{U}$ & 5.44 & 5.50 & 13.55 & 15.53 & 0.010 \\
\hline W & 38.80 & 3.90 & bdl & 2.58 & 0.700 \\
\hline $\mathrm{Y}$ & 0.12 & NA & 0.14 & 0.06 & 0.030 \\
\hline $\mathrm{Zn}$ & 56.80 & 120 & 51.14 & 134 & 5.000 \\
\hline $\mathrm{Zr}$ & 13.70 & 13.00 & 14.50 & 15.41 & 0.800 \\
\hline
\end{tabular}

bdl: below detection limit. NA: not analyzed. * data from Charoy and Noronha (1996).

\subsection{Disseminated mineralization}

\subsubsection{Argemela mine}

In the AM, $\mathrm{Sn}$-, $\mathrm{Nb}$, Ta-bearing disseminated mineralization is hosted in granitic rocks encountered at the tip of the SA-1 drill core (depth $=482-486 \mathrm{~m}$; Fig. 2: AM RMG) and in several deformed granitic dykes occurring within the metasediments (depth $=455-480 \mathrm{~m}$ ). The AM RMG shows bulk rock enrichment in Nb (76 ppm), Ta (83 ppm) and $\mathrm{Sn}(586 \mathrm{ppm})$ and depletion in $\mathrm{Ba}(31 \mathrm{ppm})$, all characteristics typical of RMGs (Černý et al., 2005; Lin- 
nen and Cuney, 2005; Table 1). Both dykes and the AM RMG show high $\mathrm{Na} / \mathrm{K}$, relatively low Li contents (105-268 ppm) and intermediate $\mathrm{P}_{2} \mathrm{O}_{5}$ concentrations $(0.32-0.44 \mathrm{wt} \%)$. These granitic rocks are characterized by millimetric snowball quartz and micas surrounded by a fine-grained white to light grey matrix (Fig. 3a). The granitic to microgranitic texture is typical of subvolcanic rocks (Müller and Seltmann 1999 and references therein). The AM RMG (dykes excluded) contains disseminated cassiterites (Cst1) and columbite-tantalites (CT 1). Cassiterites form homogeneous (i.e., unzoned) euhedral to subhedral crystals between 10 and $40 \mu \mathrm{m}$. Columbite-tantalite crystals are $30 \mu \mathrm{m}$ large on average, subhedral and show growth zonation. No Li-bearing minerals have been observed in the matrix.

\subsubsection{Cabeço da Argemela}

In the Cabeço da Argemela system, the namely Argemela RMG (see Charoy and Noronha 1996) shows bulk rock enrichments in rare metals (i.e. 62-67 ppm Nb, 62-66 ppm Ta and 635-871 ppm Sn; Table 1), in $\mathrm{Li}$ (up to 1731-4395 ppm) and in $\mathrm{P}_{2} \mathrm{O}_{5}$ (1.37-1.74 wt\%). It comprises two facies. (1) The main facies shows a granitic to microgranitic (typically subvolcanic) texture with millimetric snowball quartz and white micas embedded in a fine-grained white matrix (Fig. 3b). (2) A different facies discontinuously appears along the intrusion's border and is made of alternating aplitic and pegmatitic rocks (Fig. 2). This facies has been ascribed either to a stocksheider (Charoy and Noronha, 1996) or to unidirectional solidification textures (Inverno, 1998). Except for the northeastern border, the granite is macroscopically isotropic (i.e. underformed/unsheared). All facies from the Argemela RMG contain spread montebrasite, cassiterite and columbite-tantalite (Fig. 3; see also Charoy and Noronha, 1996). Montebrasite forms euhedral twinned crystals. The disseminated columbite-tantalite (CT I in the following) crystals are skeletal to anhedral (i.e., embayed), and clearly show growth zonation (Fig. 3c). Two generations of cassiterites can be recognized based on their general habit, zonation and inclusions. The first generation (Cst I) consists in euhedral crystals, some of them exceeding $1 \mathrm{~mm}$ in size (Fig. 3d). These cassiterites are always associated with montebrasite and appear mostly light brown in polarized light. All crystals show marked growth zonation underlining their euhedral habit. Large Cst I crystals commonly display inclusions of montebrasite (Fig. 3d) and white micas which emphasize their early growing (i.e., crystallization at the magmatic stage). Another generation of cassiterite (Cst II) corresponds to skeletal crystals, suggesting fast growth. Unlike Cst I, Cst II is not associated with montebrasite but appears as an interstitial phase surrounded by euhedral albites suggesting a fluid-present crystallization environment. Dark brown in polarized light, it contains inclusions of zoned columbite-tantalite crystals (CT II) indicating co-crystallization of the two minerals. Thus, from mineral habits (euhedral vs skeletal) and nature of inclusions (micas and montebrasite vs columbite-tantalite), one can deduce that Cst II postdate Cst I.

\subsection{Intragranitic vein-type: Structures and mineralization}

\subsubsection{Argemela mine}

Drill cores show that the hidden AM RMG is intersected by pluricentimetric to pluridecimetric veins hosting a quartz-montebrasite mineral assemblage (Fig. 3a). The montebrasite minerals occur as large crystals which can exceed several $\mathrm{cm}$ in size. These crystals are commonly twinned and subhedral. Quartz occurs as large grains with strong irreg-
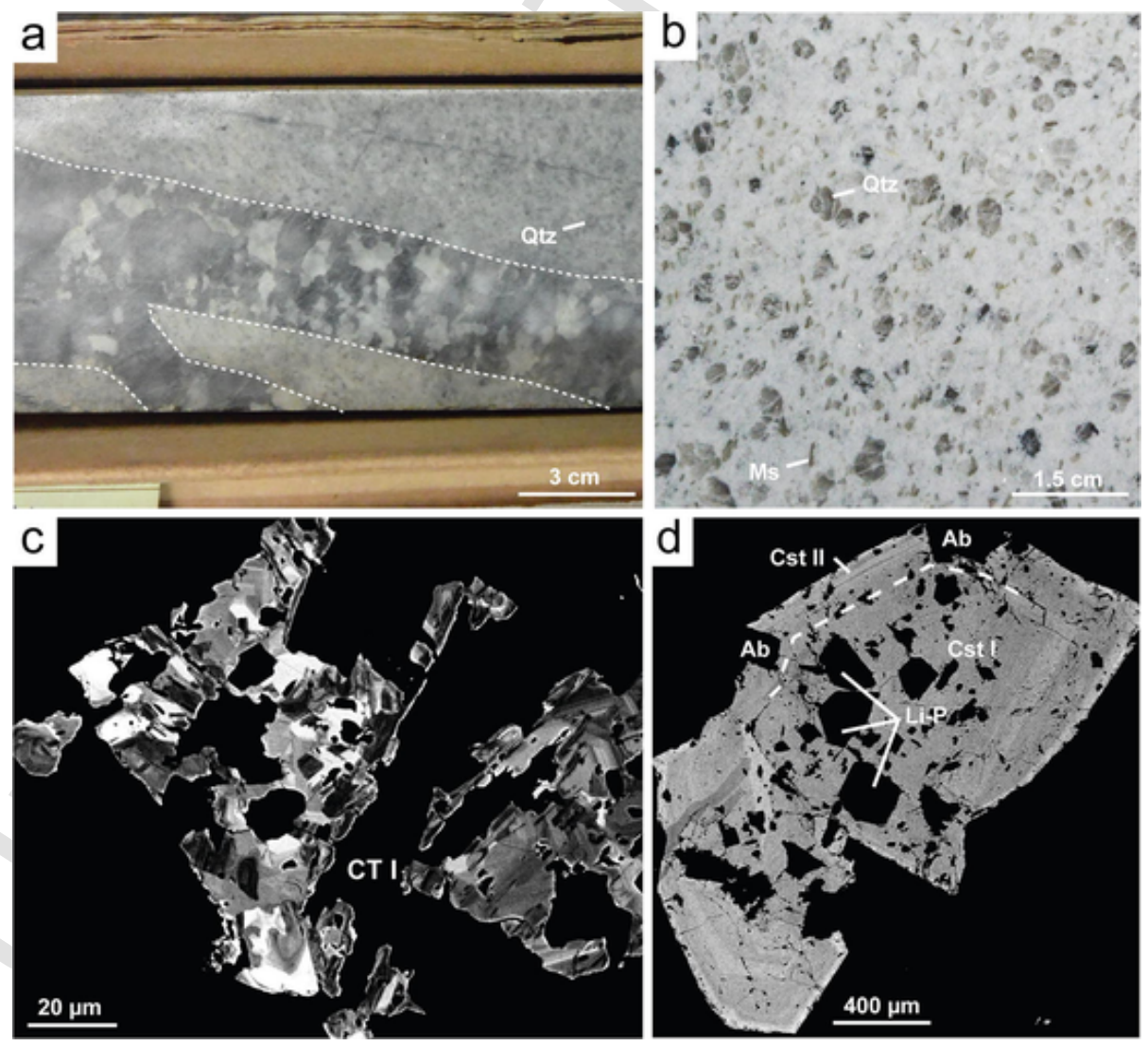

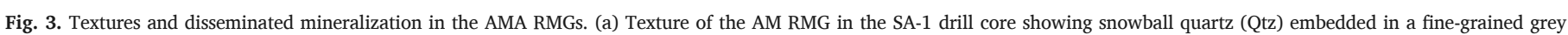

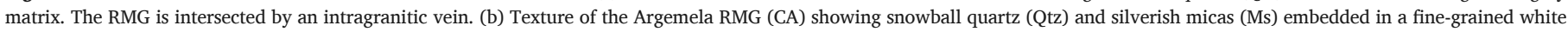

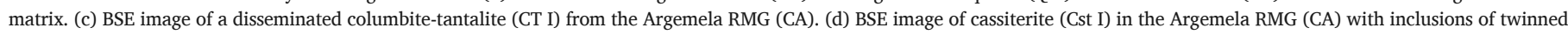
montebrasite (Li-P); the external zone associated with euhedral albite crystals (Ab) texturally corresponds to Cst II. 
ular lobate grain boundaries due to Grain Boundary Migration (GBM) recrystallization. Some grains show elongate subgrains with undulose extinction. It is noteworthy that these veins are only intragranitic and that vein opening indicates fluid circulation under still ductile to brittle conditions (i.e., at the hydrothermal stage; Michaud, 2019).

\subsubsection{Cabeço da Argemela}

The CA quarry exposes a remarkable network of intragranitic veins. Numerous and continuous observations and measurements can be made within the quarry in horizontal and vertical planes of various azimuths; additional isolated outcrops around the hill allow extrapolation of these observations to the entire granite. Three different vein families are distinguished based on (1) local crosscutting relationships, (2) vein spatial distribution and orientation and (3) type and composition of vein forming minerals (Figs. 4, 5). The three vein types systematically display vertical to steeply dipping networks. It is noteworthy that none of the encountered veins of the granite spatially extends into the country rocks.

Type I veins (Fig. 4a, b), millimetric to pluricentimetric in size, can be found in the whole quarry either clustered or isolated (Figs. 2, 4a). In a cluster, the distance between veins is of several centimeters while the distance between clusters can reach several meters (Fig. 4a). Composed of quartz, alkali feldspar and montebrasite, these veins display a peculiar "bar code" texture made of alternating mineral stripes growing perpendicular to the fracture plane (Fig. 4b). They display either straight or undulating hanging walls with ponytail terminations (Fig. 4a). The veins sometimes split into several branches showing slightly oblique orientations but, whatever their orientation, they constantly display sub-horizontal orientation of the mineral stripes. The thickness of the vein system is generally preserved when splitting occurs (i.e. the measured cumulated thicknesses of two sub-branches equals that of the original vein). Type I veins are steeply dipping and trend ENE with a $\mathrm{N} 050^{\circ} \mathrm{E}$ to $\mathrm{N} 090^{\circ} \mathrm{E}$ range, $\mathrm{N} 072^{\circ} \mathrm{E}$ on average (Fig. 2). Stereographic projection further highlights two evenly distributed sub-populations of NNW and SSE steep dip. All minerals form elongates blocky anhedral crystals (i.e. stripes) which coarsen toward the center of the veins indicating syntaxial growth. This suggests a corresponding subhorizontal displacement vector during opening of the fractures which is consistent with an extensional type development (Mode I opening, Bons et al., 2012). Discontinuity in mineral growth (especially for montebrasite) may indicate several stages of cracks. Quartz displays subgrain domains with irregular boundaries. Some relic grains show undulose extinction and GBM recrystallization. This suggests that Type I veins experienced some but limited deformation.

Type II veins, less common than Type I, occur as clusters throughout the whole quarry (Fig. 2) and are composed of dark quartz and few montebrasite. They consist in millimetric to centimetric rectilinear and continuous veins with bridges and can show branching geometry (Fig. 4c) indicating Mode I brittle failure (Bons et al., 2012). Type II veins are trending ENE (with an average trend to $\mathrm{N} 060^{\circ} \mathrm{E}$ ) and are steeply dipping to the SSE for the most (Fig. 2). Most quartz grains show clear and strong undulose extinction while some are affected by GBM recrystallization, suggesting that Type II vein were affected by late - still limited - deformation.

Type III veins can be observed everywhere in the granite (Fig. 2); they are of several $\mathrm{cm}$ wide, sometimes exceeding $15 \mathrm{~cm}$. These veins display rectilinear simple geometries with no bridge, splitting or other satellite structures as observed for Type I and II veins (Fig. 4d). Type

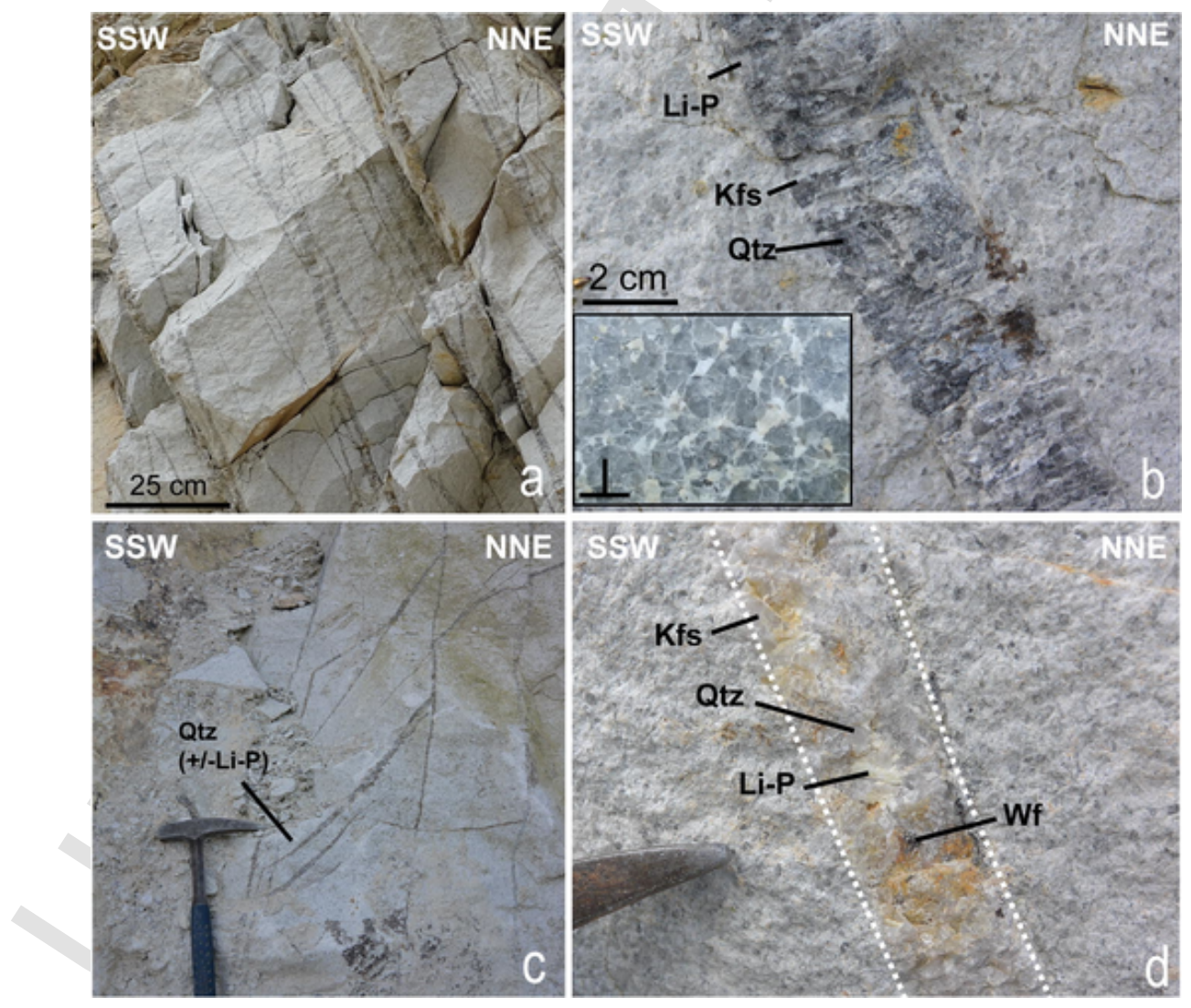

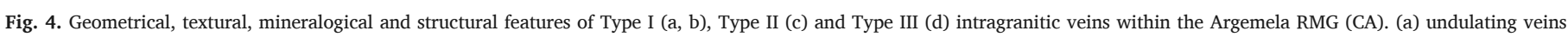

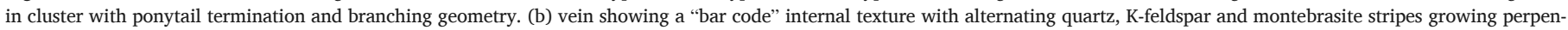

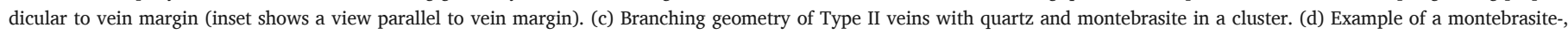
K-feldspar-, quartz-, wolframite-bearing Type III vein with a straight geometry and sharp contacts with the host rock. Li-P: montebrasite; Qtz: quartz; Kfs: K-feldspar; Wf: wolframite. 

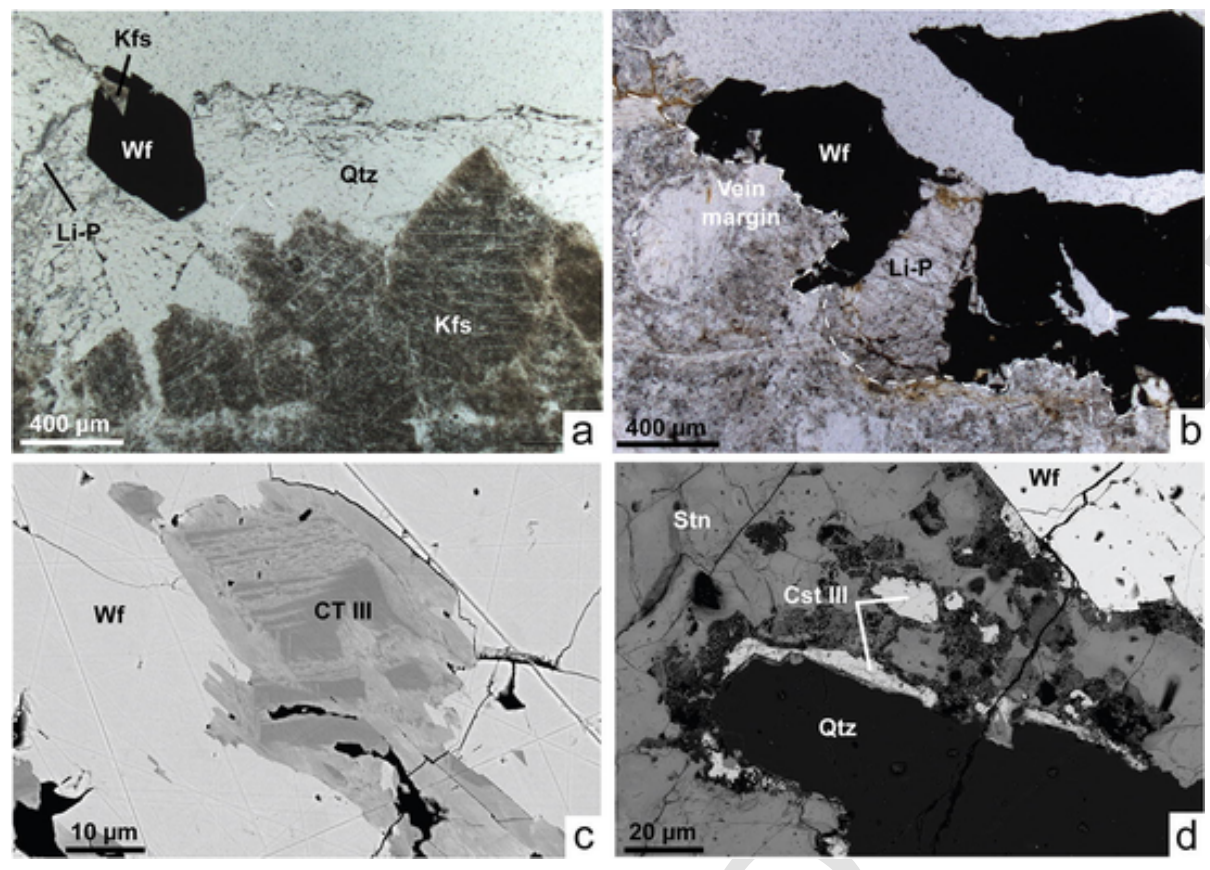

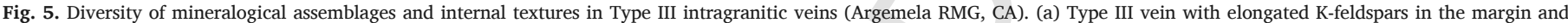

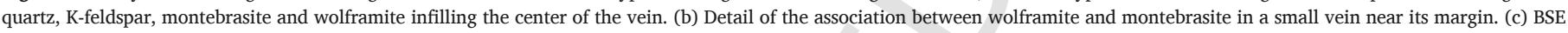

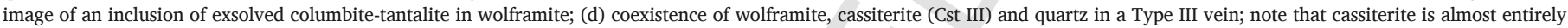
transformed into stannite. Li-P: montebrasite; Qtz: quartz; Kfs: K-feldspar; Wf: wolframite. CT III: columbite-tantalite. Cst III: cassiterite. Stn: stannite.

III veins are steeply dipping to the $\mathrm{N}$ and show a preferential orientation, trending directions ranging between $\mathrm{N} 080^{\circ} \mathrm{E}$ and $\mathrm{N} 110^{\circ} \mathrm{E}$ (Fig. 2 ). All veins show the same range of orientations, despite the variability in mineralogical assemblage, internal texture and width. The most common Type III veins (Fig. 4d) - small to medium in width - are composed of pinky hyaline quartz alkali feldspar and scarce montebrasite crystals coarsening from margins to the core. The core of veins is generally infilled by quartz showing undulose extinction, anhedral alkali feldspar, twinned montebrasite and wolframite in variable amount (Fig. 5a). Inclusion bands, mostly observed in quartz, indicate several crack-seal events. Where hanging walls are well-exposed, larger veins display asymmetrical growth of alkali feldspars and montebrasites suggesting a sinistral component of movement during vein formation, though no striae have been observed in the corresponding hanging walls. Less commonly, small veins contain wolframite (present in large amounts) and montebrasite (Fig. 5b) occurring as elongated subhedral crystals of up to several millimeters. Some wolframite crystals contain inclusions of exsolved columbite-tantalites (CT III, Fig. 5c). A single vein (Fig. 5d) was found containing blocky subhedral quartz, cassiterite (Cst III) almost entirely replaced by stannite and large amounts of wolframite.

One particular W-bearing vein is the Santa Rita vein (SR), located at the southern edge of the quarry (Fig. 2). This vein has almost entirely been excavated during exploitation making its thickness difficult to estimate. According to Inverno (1998), the SR vein strikes NE to ENE and extends from the granite to the country rocks. Thus, the SR appears to be the only intragranitic vein with a country rock extension. It shows characteristics similar to Type III veins such as the occurrence of pinky hyaline quartz. Wolframite can be observed along the vein margins, as isolated inclusions in quartz and as isolated grains pervading the granite.

Thanks to the very good exposures and numerous observations made in the field, the relative chronology between the three generations of veins looks evident with sequential development of: (i) Type I veins, (ii) Type II veins and (iii) Type III veins. Where Type III veins intersect Type I and II veins, an apparent normal movement is generally observed. It is noteworthy that no alteration halos (i.e., no noticeable mineralogical changes due to fluid-rock interaction) were observed in the granite at all vein margins, except for those located on the northeastern border, which is affected by sulphide deposition.

\subsection{Country rock vein-type mineralization}

\subsubsection{Argemela mine}

The emplacement and characteristics of the AM Sn-Li-bearing veins have been already described, among others in Inverno and Ribeiro (1980) and, formerly, in many exploration and mining internal reports. A structural model of vein formation has been proposed (Inverno and Ribeiro 1980) and is discussed below in the light of our new data.

At first, the overall structure of the mineralized veins is that of a single set of slightly oblique veins (Fig. 6a). In details, large veins often split into several smaller ones to form an anastomosed system of continuous veins and bridges (Fig. 6a). The cumulated thickness of the vein system appears constant in such configuration. All the extended veins are steeply dipping SE while bridge veins are often shallowly dipping to the SSE. Vein thicknesses range from several $\mathrm{cm}$ up to one $\mathrm{m}$ and bridges are generally thinner than continuous principal veins. Depending on their orientation, veins are either planar or folded. Planar veins are steeply dipping and trend $\mathrm{N} 069^{\circ} \mathrm{E}$ on average with $35 \%$ of them grouped between $\mathrm{N} 060^{\circ} \mathrm{E}$ and $\mathrm{N} 070^{\circ} \mathrm{E}$. The strike distribution is rather asymmetrical with a slow and continuous frequency decrease from $\mathrm{N} 069^{\circ} \mathrm{E}$ to $\mathrm{N} 090^{\circ} \mathrm{E}$ (Fig. 2). Folded veins (Fig. 6b) strike $\mathrm{N} 073^{\circ} \mathrm{E}$ on average; their frequency systematically increases from $\mathrm{N} 060^{\circ} \mathrm{E}$ to $\mathrm{N} 090^{\circ} \mathrm{E}$ with a maximum between $\mathrm{N} 080^{\circ} \mathrm{E}$ and $\mathrm{N} 090^{\circ} \mathrm{E}$. Directions for folded veins also display a skewed distribution but opposite to the one for planar veins (compare stereographic projection and rose diagrams in Fig. 2). Both planar and folded vein sets display subvertical cleavage striking $\mathrm{N} 160^{\circ} \mathrm{E}-\mathrm{N} 165^{\circ} \mathrm{E}$, parallel to the pervasive cleavage in the surrounding schists of this area (Fig. 6a, b). As a whole, the data set highlights continuous increasing rate of folding of steeply dipping veins 

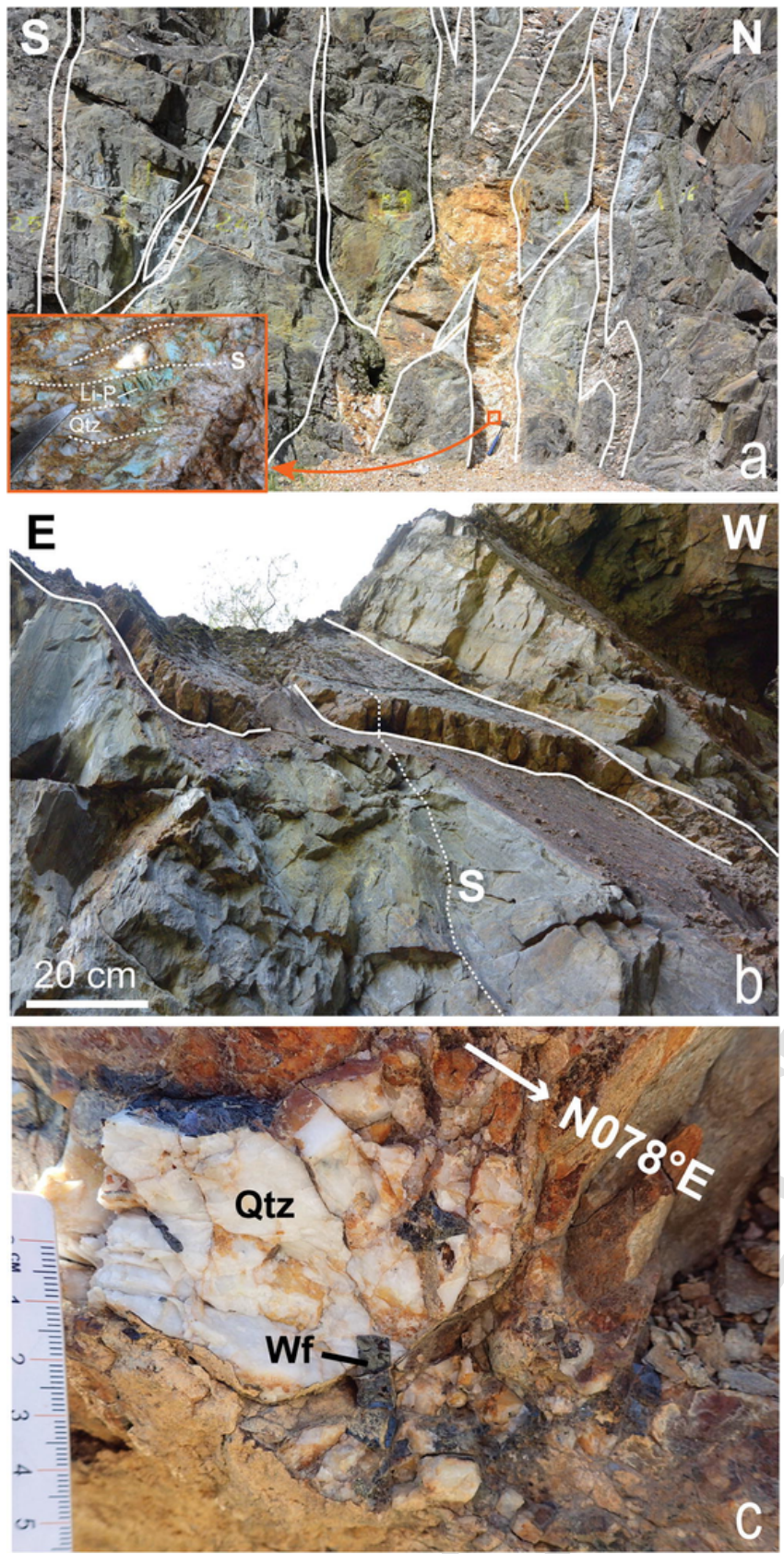

Fig. 6. Structural and mineralogical features of country rock veins in the AM (a, b) and CA (c) systems. (a) Anastomosed geometry of planar veins with branching; inset zooms in on vein internal texture; note that veins are affected by the S1 cleavage (S). (b) Folded vein seen from above and affected by the S1 cleavage (S). In (a) and (b), contacts with country rocks are accentuated (white lines). (c) Detail of the CA country rock W-bearing vein. Li-P: montebrasite; Qtz: quartz; Wf: wolframite.

from $\mathrm{N} 069^{\circ} \mathrm{E}$ striking (maximum frequency for planar ones) to $\mathrm{N} 090^{\circ} \mathrm{E}$ one (maximum frequency for folded ones).

The mineralogy of these veins consists in quartz, montebrasite and scarce cassiterite (Cst 2). Large montebrasite grains (Fig. 6a) are subhedral, can be up to several $\mathrm{cm}$ large, and are surrounded by quartz crystals. Quartz are usually observed as large relict grains with irregular lobate boundaries due to slight grain boundary migration (GBM) and recrystallization while some grains show undulose extinction. When present, cassiterite occurs mostly on the margin of the vein as isolated inclusions in quartz. This cassiterite is almost totally transformed into stannite and the vein is invaded by late phosphates and sulphides.
Besides, all veins are affected by late fractures which are systematically shallowly $\left(25-30^{\circ}\right)$ dipping either to the ENE or to the WSW (Fig. $6 a)$. As shown in well exposed vertical planes in this ancient mine, fractures clearly display as a conjugate set with angles compatible with subhorizontal NE to ENE striking principal shortening.

\subsubsection{Cabeço da Argemela}

In the CA system, isolated individual veins occur in country rocks at the immediate vicinity of the Argemela granite (Fig. 2). These include montebrasite- and wolframite-bearing veins, the latter discovered in the surrounding schists about $2 \mathrm{~m}$ away from the northeastern contact of the granite. This $\sim 3 \mathrm{~cm}$ thick vein is oriented $N 078^{\circ} \mathrm{E}, 58^{\circ} \mathrm{N}$; it is intersected by a dyke derived from the Argemela granite and is thus clearly older than granite emplacement. It consists of milky to geodic quartz and wolframite only. Quartz crystals are generally elongated and blocky along the vein margins (Fig. 6c). Crystals tend to be coarser toward the center of the vein which is characteristic of syntaxial veins (Bons et al. 2012). The center of the veins is characterized by blocky quartz, larger than those near the margin. Wolframite is present as large subhedral crystals always spatially associated with blocky quartz.

All mineralized components of the AMA are affected by a sulphide deposition stage. In the AM system, the sulphide stage results in sulphide crystallization in veins and in veinlets intersecting both the country rocks and the RMG. In the CA system, it is expressed by impregnation of sulphides along subhorizontal fractures and Type III intragranitic veins. This sulphide stage affects only the eastern sheared margin of the granite, where the map scale shear zone is located (Fig. 2).

\section{Results: Chemistry of ore minerals}

\subsection{Cassiterites}

The mineral chemistry data for all analyzed cassiterites (representative individual analyses in Table 2) are plotted on the ternary $(\mathrm{Sn}+\mathrm{Ti}+\mathrm{W})-(\mathrm{Mn}+\mathrm{Fe})-(\mathrm{Nb}+\mathrm{Ta})$ plot in Fig. 7a.

In the AM, two generations of cassiterites have been recognized. The first one (Cst 1, Fig. 7a), which corresponds to disseminated cassiterite in the AM RMG, is enriched in $\mathrm{Ta}_{2} \mathrm{O}_{5}(1-12 \mathrm{wt} \%)$ and slightly enriched in $\mathrm{Nb}_{2} \mathrm{O}_{5}(0.7-2.6 \mathrm{wt} \%)$. The second generation (Cst 2), corresponding to cassiterite in a vein emplaced within the schists, is almost pure $\mathrm{SnO}_{2}$ (Fig. 7a).

In the CA system, the disseminated light brown Cst I crystals in the Argemela RMG show oscillatory growth zonation underlining the euhedral habit of the crystal. Light brown zones are almost pure $\mathrm{SnO}_{2}$ ( $0.001 \mathrm{wt} \% \mathrm{Ta}_{2} \mathrm{O}_{5}$ and $0.15 \mathrm{wt} \% \mathrm{Nb}_{2} \mathrm{O}_{5}$ ) while darker zones have higher $\mathrm{Fe}, \mathrm{Nb}$ and Ta contents (Table 2 and Fig. 7a). In the latter, $\mathrm{Ta}_{2} \mathrm{O}_{5}$ and $\mathrm{Nb}_{2} \mathrm{O}_{5}$ can reach $7.4 \mathrm{wt} \%$ and $4.2 \mathrm{wt} \%$ respectively. The typical skeletal Cst II crystals have $\mathrm{Ta}_{2} \mathrm{O}_{5}$ between 1 and $10 \mathrm{wt} \%$ although most analyses are spread between 5 and $10 \mathrm{wt} \%$ (Fig. 7a). Crystals with dark brown overgrowths surrounded by albites (texturally Cst II) reach up to $10 \mathrm{wt} \%$ $\mathrm{Ta}_{2} \mathrm{O}_{5} . \mathrm{Nb}_{2} \mathrm{O}_{5}$ ranges between 0.5 and $6.1 \mathrm{wt} \%$, mostly between 4 and $6 \mathrm{wt} \%$. Although Cst I and II do not have strongly contrasted compositions (e.g., $\mathrm{Ta}_{2} \mathrm{O}_{5}$ and $\mathrm{Nb}_{2} \mathrm{O}_{5}$ ), Cst II are generally more enriched in $\mathrm{Ta}_{2} \mathrm{O}_{5}$ and $\mathrm{Nb}_{2} \mathrm{O}_{5}$ than Cst I. The last generation of cassiterite in Type III intragranitic veins is almost pure $\mathrm{SnO}_{2}(97-100 \mathrm{wt} \%$, Table 2 and Fig. $7 \mathrm{a})$ and contains significant $\mathrm{Fe}(0.4-1.1 \mathrm{wt} \%)$ and remarkably high $\mathrm{W}$ contents up to $2.4 \mathrm{wt} \% \mathrm{WO}_{3}$.

It is important to note that, in the two mineralized systems, disseminated cassiterites are enriched in $\mathrm{Ta}_{2} \mathrm{O}_{5}$ and $\mathrm{Nb}_{2} \mathrm{O}_{5}$ compared to cassiterites from veins showing enrichments in Fe and W. All Cst 1, Cst 2, Cst I and Cst II extend from the $\mathrm{Sn}+\mathrm{Ti}+\mathrm{W}$ corner of the ternary diagram along the trend defined by the ideal substitution $(\mathrm{Fe}, \mathrm{Mn})^{2+}$ $+2(\mathrm{Nb}, \mathrm{Ta})^{5+} \leftrightarrow 3(\mathrm{Sn}, \mathrm{Ti})^{4+}$ (Černý et al., 1985, Fig. 7a). Disseminated cassiterites in the CA system indicate increased substitution from Cst I to Cst II. The intragranitic vein cassiterites (Cst III) plot on the 
Table 2

Representative major and minor element composition of cassiterites determined by EPMA.

\begin{tabular}{|c|c|c|c|c|c|c|c|c|c|c|}
\hline System & $\mathrm{CA}$ & & & & & & $\mathrm{AM}$ & & & \\
\hline \multirow[t]{3}{*}{ Type } & Disseminated & & & & Vein & & Disseminated & & Vein & \\
\hline & Cst I & & Cst II & & Cst III & & Cst 1 & & Cst 2 & \\
\hline & Light zone & Dark zone & & & & & & & & \\
\hline $\mathrm{TiO}_{2}$ & bdl & - & 0.04 & - & - & - & 0.65 & 0.40 & - & bdl \\
\hline $\mathrm{MnO}$ & bdl & 0.21 & 0.12 & 0.11 & bdl & - & 0.02 & - & - & - \\
\hline $\mathrm{FeO}$ & 0.19 & 1.16 & 1.52 & 1.20 & 0.84 & 1.13 & 1.28 & 0.34 & 0.09 & 0.09 \\
\hline $\mathrm{Nb}_{2} \mathrm{O}_{5}$ & 1.09 & 2.37 & 0.74 & 4.88 & bdl & - & 2.21 & 0.73 & - & bdl \\
\hline $\mathrm{SnO}_{2}$ & 99.98 & 91.46 & 88.56 & 91.56 & 98.08 & 98.82 & 92.12 & 97.95 & 100.39 & 100.70 \\
\hline $\mathrm{Ta}_{2} \mathrm{O}_{5}$ & 0.10 & 5.66 & 9.23 & 2.03 & - & - & 4.31 & 1.00 & - & bdl \\
\hline $\mathrm{WO}_{3}$ & bdl & - & NA & NA & 1.52 & 0.21 & - & - & 0.09 & - \\
\hline Total & 101.94 & 101.32 & 100.63 & 100.24 & 100.93 & 100.67 & 101.08 & 100.90 & 101.65 & 101.53 \\
\hline $\mathrm{Ti}$ & - & - & 0.001 & - & - & - & 0.012 & 0.008 & - & - \\
\hline Mn & - & 0.004 & 0.003 & 0.002 & - & - & - & - & - & - \\
\hline $\mathrm{Fe}$ & 0.004 & 0.024 & 0.032 & 0.025 & 0.017 & 0.023 & 0.026 & 0.007 & 0.002 & 0.002 \\
\hline $\mathrm{Nb}$ & 0.012 & 0.026 & 0.008 & 0.054 & - & - & 0.025 & 0.008 & - & - \\
\hline Sn & 0.975 & 0.899 & 0.887 & 0.896 & 0.970 & 0.979 & 0.901 & 0.964 & 0.991 & 0.992 \\
\hline Тa & 0.001 & 0.038 & 0.063 & 0.014 & - & - & 0.029 & 0.007 & - & - \\
\hline W & - & - & - & - & 0.010 & 0.001 & - & - & 0.001 & - \\
\hline Total & 1.005 & 1.004 & 1.005 & 1.003 & 1.010 & 1.018 & 1.007 & 1.006 & 1.008 & 1.007 \\
\hline
\end{tabular}

bdl: below detection limit. Oxides in wt\%. NA: not analyzed. Number of cations based on 2 oxygens

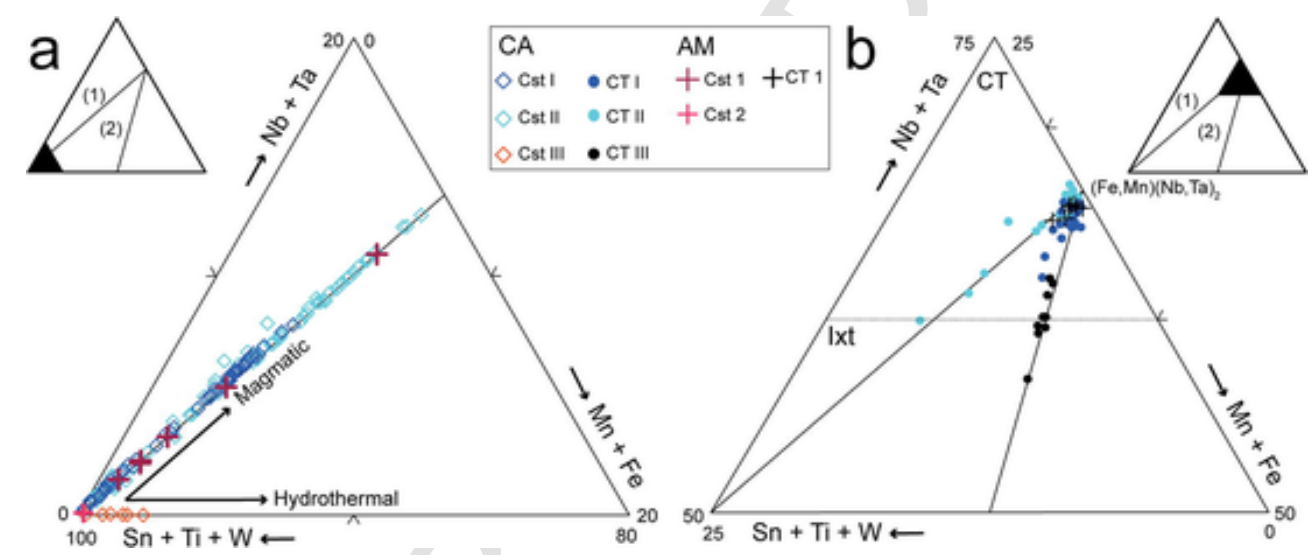

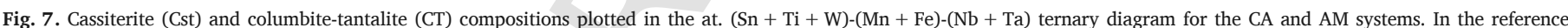

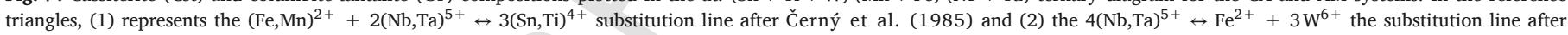

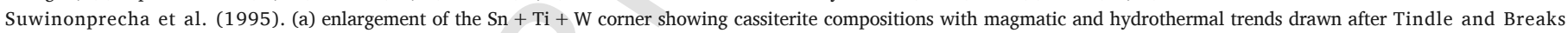
(1998) and Breiter et al. (2007); (b) enlargement showing columbite-tantalite compositions. The horizontal dashed line marks the CT-Ixt boundary. Ixt = ixtiolite.

$(\mathrm{Sn}+\mathrm{Ti}+\mathrm{W})-(\mathrm{Mn}+\mathrm{Fe})$ side as compositions are almost Nb-, Ta-free and Fe-, W-rich.

\subsection{Columbite-tantalites}

Columbite-tantalite compositions (Table 3 ) are plotted in the same ternary $(\mathrm{Sn}+\mathrm{Ti}+\mathrm{W})-(\mathrm{Mn}+\mathrm{Fe})-(\mathrm{Nb}+\mathrm{Ta})($ Fig. $7 \mathrm{~b})$ and binary $\mathrm{Ta} /($ $\mathrm{Ta}+\mathrm{Nb})-\mathrm{Mn} /(\mathrm{Mn}+\mathrm{Fe})($ Fig. 8) diagrams.

In the $\mathrm{AM}$ system (Fig. $7 \mathrm{~b}, 8$ ), the single generation of columbite-tantalite observed in the RMG consists in disseminated Fe-columbite. Most compositions do not exceed $\mathrm{Ta} /(\mathrm{Ta}+\mathrm{Nb})=0.4$ except one analysis which has $\mathrm{Ta} /(\mathrm{Ta}+\mathrm{Nb})=0.6$ and plots in the Fe-tantalite field. Compositions are homogeneous and plot close to the $(\mathrm{Nb}+\mathrm{Ta})-(\mathrm{Mn}+\mathrm{Fe})$ side of the ternary diagram (Fig. 7b).

In the CA system, three generations of columbite-tantalites are recognized (Figs. 7b, 8). Disseminated CT I in the Argemela RMG is $\mathrm{Mn}$-columbite with compositions ranges of $\mathrm{Mn} /(\mathrm{Mn}+\mathrm{Fe})=$ from 0.7 to
0.9 and $\mathrm{Ta} /(\mathrm{Ta}+\mathrm{Nb})=$ from 0.1 to 0.4 . CT II in the Argemela RMG (zoned inclusions in Cst II) are Mn-columbites to Mn-tantalites. They have $\mathrm{Mn} /(\mathrm{Mn}+\mathrm{Fe})=$ from 0.6 to 0.8 , in the same range as CT I but with a higher $\mathrm{Ta} /(\mathrm{Ta}+\mathrm{Nb})$ ratio between 0.3 and 0.8 . The CT III crystals included in some wolframites of Type III intragranitic vein show only Mn-columbite compositions. They have $\mathrm{Mn} /(\mathrm{Mn}+\mathrm{Fe})$ ratios between 0.5 and 0.6 and are thus more Fe-rich than CT I and CT II. In the ternary $(\mathrm{Sn}+\mathrm{Ti}+\mathrm{W})-(\mathrm{Mn}+\mathrm{Fe})-(\mathrm{Nb}+\mathrm{Ta})$ diagram (Fig. 7a), disseminated CT I plot close to the $(\mathrm{Nb}+\mathrm{Ta})-(\mathrm{Mn}+\mathrm{Fe})$ side and are spread between the two ideal substitution lines $(\mathrm{Fe}, \mathrm{Mn})^{2+}+2(\mathrm{Nb}, \mathrm{Ta})^{5+} \leftrightarrow$ $3(\mathrm{Sn}, \mathrm{Ti})^{4+}$ (Černý et al. 1985 ) and $4(\mathrm{Nb}, \mathrm{Ta})^{5+} \leftrightarrow \mathrm{Fe}^{2+}+3 \mathrm{~W}^{6+}$ (Suwinonprecha et al. 1995; Neiva 1996, Fig. 7b) so that the incorporation of W and Sn in CT I is controlled by the two substitutions. Inclusions of CT II in Cst II and of CT III in wolframite plot along the first and second substitution line respectively suggesting that the corresponding mechanisms control incorporation of Sn in CT II and of W and Fe in CT III. 
Table 3

Representative major and minor element composition of colombite-tantalites determined by EMPA.

Expand

\begin{tabular}{|c|c|c|c|c|c|c|c|c|}
\hline \multirow{2}{*}{$\begin{array}{l}\text { System } \\
\text { Type }\end{array}$} & \multicolumn{5}{|l|}{ CA } & \multicolumn{3}{|c|}{$\mathrm{AM}$} \\
\hline & CT I & & CT II & & & & & \\
\hline $\mathrm{TiO}_{2}$ & 0.31 & 0.62 & 0.67 & 0.05 & 0.39 & 0.49 & 0.46 & 1.18 \\
\hline $\mathrm{MnO}$ & 16.42 & 16.21 & 11.78 & 13.90 & 10.41 & 10.10 & 8.09 & 3.54 \\
\hline $\mathrm{FeO}$ & 2.47 & 2.98 & 3.88 & 4.06 & 8.91 & 9.16 & 9.73 & 15.78 \\
\hline $\mathrm{Nb}_{2} \mathrm{O}_{5}$ & 53.67 & 55.17 & 23.37 & 44.71 & 45.49 & 48.24 & 41.69 & 56.77 \\
\hline $\mathrm{SnO}_{2}$ & 0.07 & 0.22 & 1.98 & 0.35 & 0.08 & 0.08 & 0.19 & 0.45 \\
\hline $\mathrm{Ta}_{2} \mathrm{O}_{5}$ & 26.75 & 23.93 & 58.44 & 36.89 & 27.29 & 27.05 & 40.24 & 24.12 \\
\hline $\mathrm{WO}_{3}$ & - & 0.08 & - & - & 7.63 & 5.30 & - & - \\
\hline Total & 99.69 & 99.21 & 100.13 & 99.96 & 100.21 & 100.41 & 100.49 & 101.88 \\
\hline $\mathrm{Ti}$ & 0.014 & 0.029 & 0.037 & 0.003 & 0.019 & 0.024 & 0.023 & 0.054 \\
\hline Mn & 0.875 & 0.858 & 0.730 & 0.775 & 0.570 & 0.545 & 0.455 & 0.182 \\
\hline $\mathrm{Fe}$ & 0.130 & 0.156 & 0.237 & 0.223 & 0.482 & 0.488 & 0.541 & 0.800 \\
\hline $\mathrm{Nb}$ & 1.527 & 1.559 & 0.773 & 1.331 & 1.329 & 1.392 & 1.252 & 1.557 \\
\hline Sn & 0.002 & 0.006 & 0.058 & 0.009 & 0.002 & 0.002 & 0.005 & 0.011 \\
\hline $\mathrm{Ta}$ & 0.458 & 0.407 & 1.163 & 0.660 & 0.480 & 0.469 & 0.727 & 0.398 \\
\hline W & - & 0.001 & - & - & 0.128 & 0.088 & - & - \\
\hline Total & 3.007 & 3.015 & 3.000 & 3.002 & 3.010 & 3.008 & 3.003 & 3.003 \\
\hline
\end{tabular}

Oxides in wt $\%$. Number of cations based on 6 oxygens

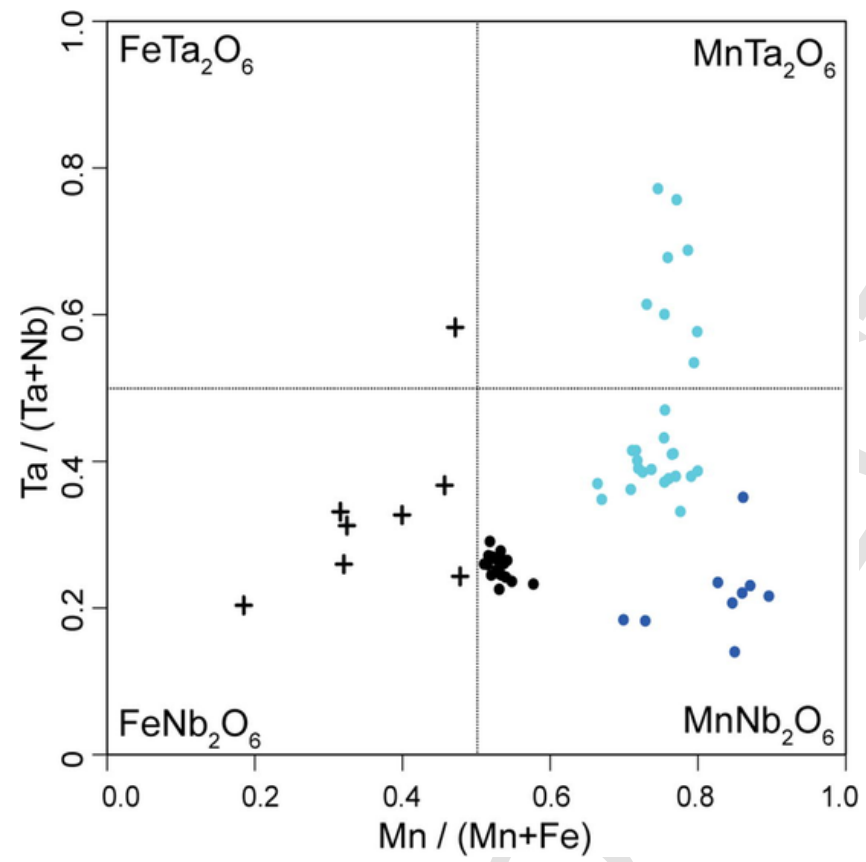

Fig. 8. at. $\mathrm{Ta} /(\mathrm{Ta}+\mathrm{Nb})-\mathrm{Mn} /(\mathrm{Mn}+\mathrm{Fe})$ binary diagram showing columbite-tantalite compositions from this study. Same legend as in Fig. 7.

\subsection{Wolframites}

Two generations of wolframites can be recognized in the CA system. Wolframite in the isolated country rock vein shows a patchy texture with Mn and Fe-rich domains (Michaud and Pichavant, 2019) suggesting two stages of wolframite crystallization (Llorens and Moro, $2012 \mathrm{a}, 2012 \mathrm{~b})$. Early wolframites have a $\mathrm{H} / \mathrm{F}$ ratio $(\mathrm{H} / \mathrm{F}=$ at. $\mathrm{Mn} / \mathrm{C}$ $\mathrm{Fe}+\mathrm{Mn}) \times 100$ ) of $62 \%$ on average (hübnerites) decreasing to $\sim 10 \%$ on average (ferberites) for late wolframites (compositional data in Michaud and Pichavant, 2019). Wolframites in Type III intragranitic veins are mostly homogeneous hübnerites (H/F: 67-75\%). In con- trast, wolframites associated with montebrasite in the Santa Rita vein (SR) show a patchy texture and an evolution toward lower $\mathrm{H} / \mathrm{F}$ ratios (55-46\%; hübnerite to Mn-rich ferberite, Michaud and Pichavant, 2019). Therefore, both in intragranitic and country rock veins, early crystallized wolframites are Mn-rich (hübnerites) and late wolframites always more Fe-rich. Yet, there is a difference between late wolframites in the country rock vein and in intragranitic Type III veins since the former are much more Fe-rich than the latter.

\subsection{Montebrasites}

Major element compositions of montebrasites do not vary much (Table 4); these are mostly montebrasites with 59 to $76 \%$ Mtb (i.e., $\mathrm{Mtb}=100 * \mathrm{OH} / 2$ with $\mathrm{OH}=2-\mathrm{F}$ apfu). Montebrasites from hydrothermal veins show only a slight enrichment in F compared to disseminated montebrasites. No growth zonation has been observed.

Table 4

Representative major and minor element composition of montebrasites determined by EPMA.

Expand

\begin{tabular}{|c|c|c|c|c|c|c|c|}
\hline \multirow{2}{*}{$\begin{array}{l}\text { System } \\
\text { Type }\end{array}$} & \multicolumn{3}{|l|}{ CA } & \multicolumn{4}{|l|}{$\mathrm{AM}$} \\
\hline & Dispersed & $\begin{array}{l}\text { Type III } \\
\text { veins }\end{array}$ & & $\begin{array}{l}\text { Intragr } \\
\text { veins }\end{array}$ & & $\begin{array}{l}\text { Count } \\
\text { veins }\end{array}$ & rock \\
\hline $\mathrm{P}_{2} \mathrm{O}_{5}$ & 49.80 & 48.38 & 48.84 & 49.97 & 48.75 & 48.97 & 48.64 \\
\hline $\mathrm{Al}_{2} \mathrm{O}_{3}$ & 36.10 & 34.09 & 33.78 & 33.22 & 33.23 & 32.99 & 33.94 \\
\hline $\mathrm{TiO}_{2}$ & 0.06 & - & 0.01 & 0.27 & 0.32 & 0.18 & 0.16 \\
\hline $\mathrm{F}$ & 3.23 & 5.38 & 3.78 & 3.19 & 4.43 & 4.85 & 4.03 \\
\hline $\mathrm{O}=\mathrm{F}$ & 1.36 & 2.27 & 1.59 & 1.34 & 1.86 & 2.04 & 1.69 \\
\hline Total & 87.95 & 85.65 & 84.83 & 85.43 & 85.03 & 85.12 & 85.26 \\
\hline $\mathrm{P}$ & 1.971 & 1.951 & 1.931 & 2.028 & 1.985 & 1.988 & 1.979 \\
\hline $\mathrm{Al}$ & 1.879 & 1.808 & 1.862 & 1.773 & 1.779 & 1.761 & 1.816 \\
\hline $\mathrm{Ti}$ & 0.002 & - & - & 0.010 & 0.012 & 0.006 & 0.006 \\
\hline $\mathrm{F}$ & 0.477 & 0.811 & 0.735 & 0.484 & 0.674 & 0.736 & 0.612 \\
\hline $\mathrm{OH}$ & 1.523 & 1.189 & 1.424 & 1.516 & 1.326 & 1.264 & 1.388 \\
\hline$\% \mathrm{Mtb}$ & 76.1 & 59.4 & 71.2 & 75.8 & 66.3 & 63.2 & 69.4 \\
\hline
\end{tabular}

Oxides in wt $\%$. Number of cations based on 8 oxygens 


\section{Discussion}

\subsection{Linking the different mineralized components forming the AMA}

Rare metal Li, Sn, Nb, Ta and $\mathrm{W}$ mineralization in the AMA is separated in two neighboring but spatially disconnected systems sharing common features: (i) mineralized granites, (ii) mineralized intragranitic veins and (iii) mineralized country rock veins. Both systems are Sn-Li-(Nb-Ta)-dominated with only minor $\mathrm{W}$ content and they strongly differ from the $\mathrm{W}$-(Sn-Cu)-dominated granite-related Panasqueira deposit nearby. The spatial juxtaposition of three ore-forming stages (magmatic, magmatic-hydrothermal, hydrothermal) as observed in the AMA is quite exceptional among Variscan granite-related rare metal deposits. Indeed, RMG emplacement is not always associated with vein mineralization as observed for the Beauvoir granite (Aubert 1969; Raimbault et al. 1995). In the same way, Panasqueira is well known for its country rock vein system but, up to now, it has not been evidenced that a RMG would be the source of fluids and metals (Kelly and Rye 1979; Neiva 2008; Lecumberri-Sanchez et al., 2017). Several mineralized intragranitic vein systems (Cligga Head: Smith et al., 1996; Cinovec: Breiter et al., 2017; Korges et al., 2018) lack counterparts in country rocks. In contrast, in the AMA, the three mineralization stages are all present together and, so, their mutual relations can be deciphered.

The three mineralizing stages are not developed to the same extent in the AM and the CA (Fig. 9). The AM mainly displays occurrences of hydrothermal processes marked by the Sn-Li vein swarm hosted in country rocks. Such hydrothermal system could genetically be linked to the granitic dykes or to the RMG, as observed around $\sim 450-480 \mathrm{~m}$ depth along the SA-1 drill core, or to both intrusions. At first, these dykes are sheared whereas the RMG is isotropic and it hosts intragranitic veins. Secondly, certain notable geochemical distinctions exist between the dyke and the RMG (e.g., As, Table 1). Such features show that the granitic components lying deep under the AM must correspond to two distinct magmatic pulses. Granitic dykes are most probably related to a hidden granite apophyse while the RMG followed an independent evolution resulting in disseminated mineralization and intragranitic hydrothermal veins. As observed at surface, the size of the Sn-Li vein swarm of the AM evidences for large amount of hydrothermal fluids; the restricted size of RMG observed in the AM would hardly accounts for such volume and an additional magmatic fluid source must be required. In addition, our structural study clearly shows that veins deformed just as the granitic dyke to depth. We thus infer that both the dykes and the vein swarm emanate from a hypothetical granitic apophyse at depth, as proposed by Inverno and Ribeiro (1980).

In contrast, mineralization in the CA is mainly related to magmatic processes and to the magmatic-hydrothermal transition as marked by the disseminated ore minerals in the Argemela RMG, and the mineralized intragranitic veins (Fig. 9). On the actual level of exposure, hydrothermal processes in country rocks are almost lacking as solely one isolated wolframite-bearing vein has been observed into the schists. However, the Argemela RMG crosscuts this specific vein and this one marks thus an early ore-forming stage preceding the RMG intrusion. This hydrothermal vein must be related to another granitic intrusion at depth.

We conclude that the two mineralized systems forming the AMA are complementary from each other: as a whole, they expose an almost entire succession of mineralizing processes, from magmatic to hydrothermal (Fig. 9). Yet, there are first-order differences between the two systems, for example in magma emplacement levels, deeper in the AM than in the CA. Also, the well-developed hydrothermal vein system of the AM has no equivalent in the CA. The relative chronology of the AM and CA is still unconstrained, and the two systems must be considered as genetically independent. However, it remains to be tested whether they form part of the same local metallogenic evolution. Below, we use the respective structural and tectonic contexts of vein emplacement to further examine the relations between the two systems.

\subsection{Structural contexts of vein emplacement}

The structural analysis of the montebrasite-bearing veins of the AM system clearly evidences non-coaxial shearing compatible with $\sim$ N170-NS striking dextral shearing during the development of the vein swarm into the schists. Both planar and folded veins are affected by the pervasive subvertical $\mathrm{N} 160-165^{\circ} \mathrm{E}$ striking cleavage as measured in the country rocks. Compared to its regional-scale average $\mathrm{N} 130-135^{\circ} \mathrm{E}$ striking, this local reorientation of cleavage planes is compatible with the development of a km scale wide, N170-NS striking dextral shear band. Besides, localized shearing evidences of the same direction are exposed in the Argemela RMG, along its northeastern border (Michaud, 2019). In such structural framework, early veins must have developed as subvertical tension gashes in an initial $\sim$ NE striking (i.e. parallel to the $\sigma 1$ maximum stress axis and at $\sim 45^{\circ}$ from the simple shear direction, Fig.

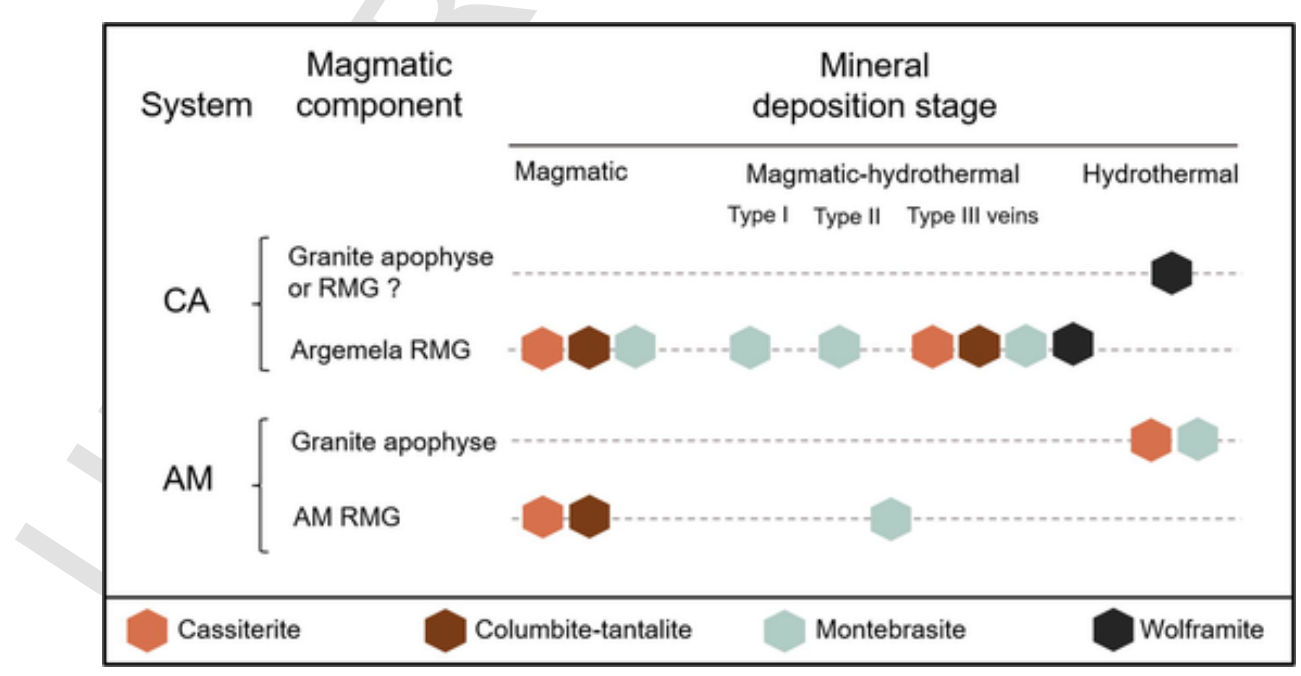

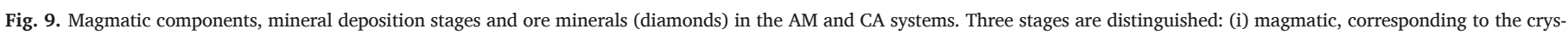

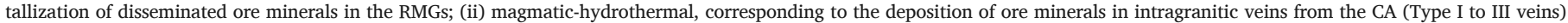

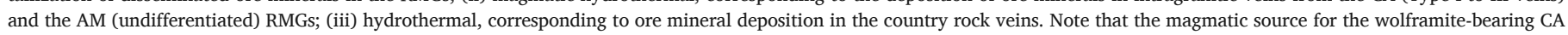
country rock vein is hypothetical (granite apophyse or RMG?). See text for additional details and explanations. 
10). During the ongoing simple shearing, these earliest veins of the swarm rotated clockwise, and folded to accommodate longitudinal finite shortening. In the meanwhile, new generations of veins steadily developed parallel to $\sigma 1$ and undergo the same deformational steps while buckling and clockwise rotation of early veins continue. The final state shows the earliest veins as the more folded and having rotated up to $\sim \mathrm{N} 80-90^{\circ} \mathrm{E}$ striking (Fig. 10 ), intermediate generations with more limited buckling and rotation and the last veins developed still planar and parallel to the $\sigma 1$ axis, in their original striking. Such a model of progressive veins emplacement, rotation and shearing, in a dextral simple shear framework, is consistent with the regional NE trending maximum stress and the steep attitude of all veins is compatible with subhorizontal $\sigma 3$ axis (Fig. 10), as suggested by Inverno and Ribeiro (1980). However, in contrast with the model these authors proposed, veins orientation can be explained by the local tectonic regime, as the principal controlling factor, with no necessity to involve the emplacement of a granitic apophyse to depth.
Development of the CA system highly suggests that strong links exist between veins formation and granite emplacement. Indeed, none of the veins observed within the Argemela RMG extends into country rocks. Moreover, three types of intragranitic veins have been recognized - Type I to Type III - with a clear successive development; the evolution of geometries and textures shown in this study evidence a change in granite behavior from ductile/brittle to pure brittle (Fig. 4). This differs from the behavior of the Beira schists, which must have remained ductile during emplacement of the vein swarm in the AM system. Besides, no vein folding has been observed in the granite probably due the rigid behavior of the intrusion relative to the surrounding schists. In contrast with the Type I \& II extensional veins, asymmetrical mineral growth in the latest Type III $\sim \mathrm{N} 95^{\circ} \mathrm{E}$ striking veins indicates a sinistral component of movement along vein planes during emplacement (shear fractures; Bons et al. 2012) with $\alpha=55^{\circ}$ (angle between $\sigma 3$ and shear plane; Bons et al. 2012). This structure is fully compatible with the stress regime evidenced from the AM system structures

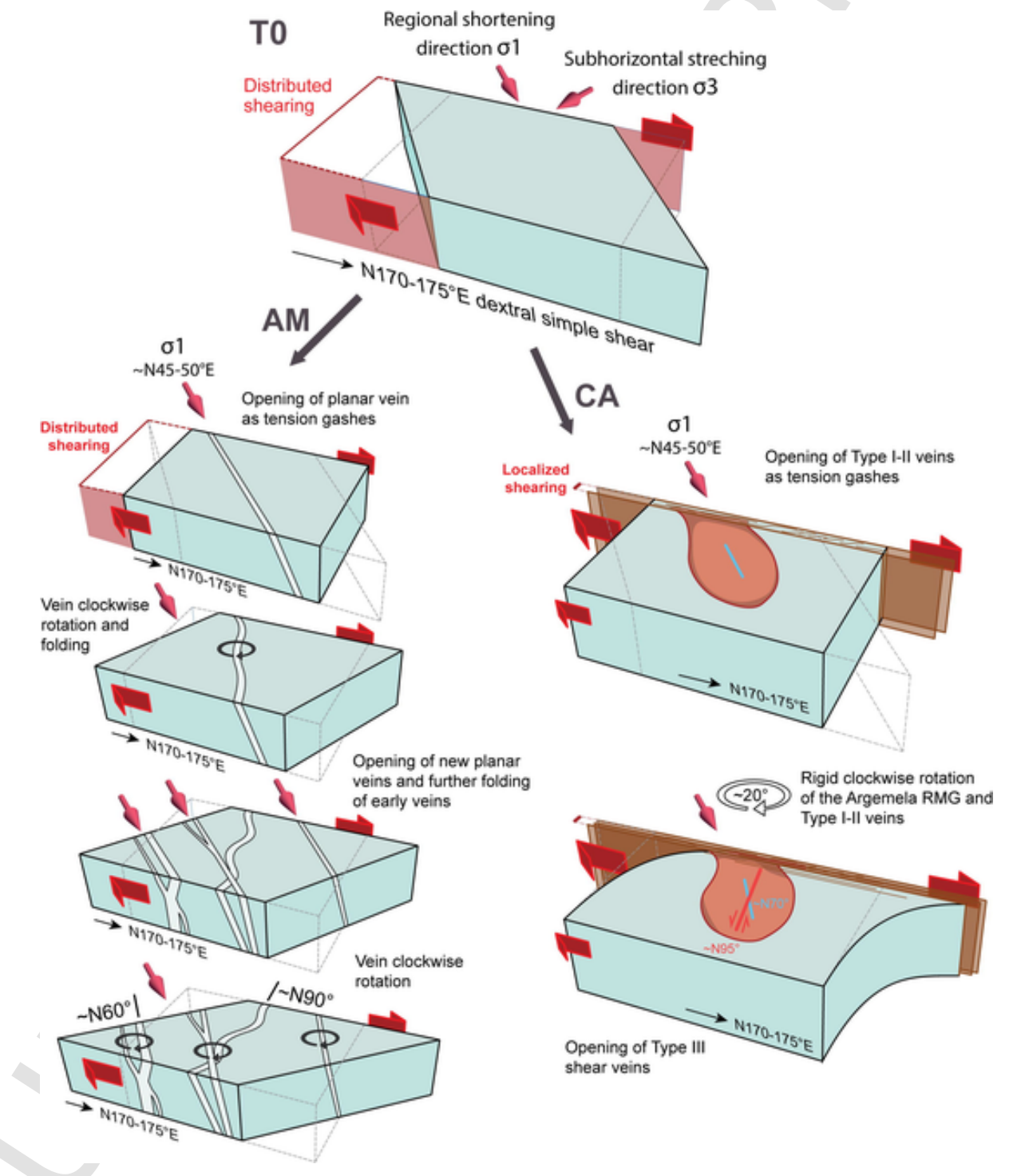

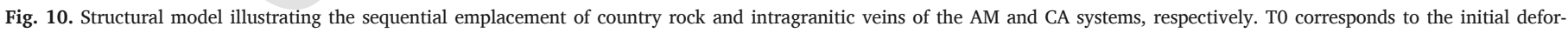

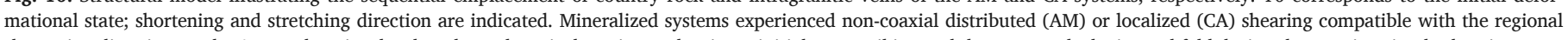

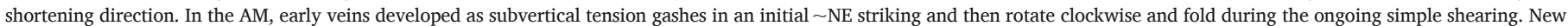

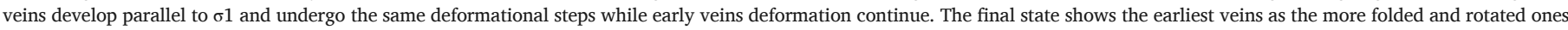

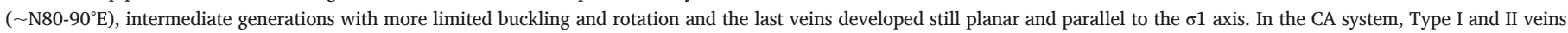

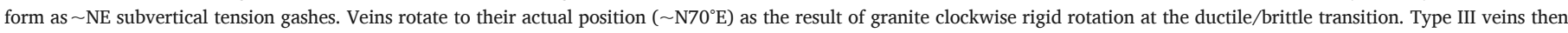
open as subvertical $\sim \mathrm{N} 095^{\circ} \mathrm{E}$ shear veins when the intrusion behave as a brittle body. 
(see above) and subhorizontal $\sim \mathrm{NE}$ striking $\sigma 1$ and $\sim \mathrm{NW}$ striking $\sigma 3$, at regional scale. On the contrary, the current average orientation of extensional Type I and II intragranitic veins of the CA is not consistent as not parallel to such NE-SW regional $\sigma 1$ axis direction (Fig. 2). This could indicate that the CA Type I \& II intragranitic veins formed in a structural context different from that specified for the AM and different from the one evidenced for later Type III veins. However, this would imply significant stress rotation during granite crystallization, an unlikely hypothesis given the short time lapses induced (e.g. 4 My maximum for a larger granitic body, Scaillet et al., 1996a, 1996b). Likewise, the localized dextral shear corridor affects the northeastern border of the intrusion (Michaud, 2019; Fig. 2) with development of shear planes suggesting that the granite cooled during simple shearing. In fact, localization of the strain along the shear planes bordering the granite shows that the intrusion was much more viscous compared to the surrounding schists where deformation is pervasive. Furthermore, no macroscopic deformation has been observed in the core of the Argemela granite. This added to the pipe-like geometry of the magmatic body (see Michaud, 2019), suggests that simple dextral shearing could have led to some clockwise rigid rotation of the whole intrusion around a vertical axis (Fig. 10). In such a setting, the earlier Type I and II veins could have initially opened vertically in a $\sim$ NE striking, consistent with their extensional type character and the regional-scale principal stress axes orientation. Then, the intrusion together with the veins rotated by about $20^{\circ}$ clockwise (Fig. 10) before development of the Type III veins. Late-magmatic rotations have been described on bigger intrusions of the French Massif Central (see Olivier and Améglio 2002 and references therein). Considering a clockwise $\sim 20^{\circ}$ rotation of Type I \& II veins, the strike angles of the overall veins set is consistent with a N170-NS dextral shear corridor and NE striking regional-scale $\sigma 1$ (Michaud, 2019) during granite emplacement. Consequently, textural and geometrical specificities between, on the one hand, the Type I and II and, on the other hand, the Type III veins of CA reflect a deformation continuum at the magmatic-hydrothermal transition as the granite intrusion progressively cooled and crystallized. We conclude that both veins from the AM and the CA systems emplaced in the same structural and tectonic framework and thus most probably form parts of the same integrated metallogenic evolution.

\subsection{Mineralizing processes and sequence}

The metallogenic evolution in the AMA includes a continuous magmatic to hydrothermal sequence of transport, concentration and deposition mechanisms (Fig. 9). In the AM and CA RMGs, the Sn-Nb-Ta-Li disseminated minerals indicate metal concentration and precipitation in the granite bodies. Both RMGs host cassiterite and columbite-tantalite while montebrasite is only observed in the CA (Argemela RMG; Fig. 9). This emphasizes the general geochemical similarity between these two highly evolved albeit non-cogenetic granites. Early cassiterites (Cst 1 and Cst I in the AM and CA respectively) are found in the whole granite masses and, in the Argemela RMG, Cst I (with euhedral habit and growth zonation) is associated with montebrasite (Fig. 3d). This strongly suggests cassiterite crystallization at the magmatic stage. Only Fe-columbite occurs in the AM while, in the Argemela RMG, CT I are Mn-columbites (Fig. 8). Therefore, the AMA RMGs constitute examples of evolved cassiterite- and columbo-tantalite-bearing igneous rocks such as known in the Variscan belt and elsewhere (e.g., Cuney et al. 1992; Raimbault et al., 1995; Neiva 1996; Raimbault and Burnol, 1998; Černý et al. 2005; Breiter et al. 2017). Precipitation of Sn, Nb, Ta minerals in such evolved granites and pegmatites has been interpreted as magmatic (see 6.4). In the same way, the composition of montebrasite (Table 4) implies a F content in the coexisting melt of $\sim 1 \mathrm{wt} \%$ (London et al., 2001), in agreement with the range of F concentrations in the Argemela granite (Table 1) and consistent with montebrasite also crystallizing as a magmatic phase.

The second generation of cassiterite (Cst II) encloses zoned Mn-columbite to Mn-tantalite (CT II) suggesting their co-crystallization. The Cst II habit suggests fast growth possibly assisted by a fluid phase and, therefore, crystallization of disseminated Cst II is taken as the earliest indication for granite crystallization in presence of fluid, i.e., for fluid exsolution from the magma at the beginning of the magmatic-hydrothermal transition. Vein emplacement within the Argemela RMG postdates the co-crystallization of Cst II and CT II in the granite mass. Being confined within the granite with no extension into country rocks, the intragranitic vein system corresponds to magmatic fluids exsolved from the crystallizing body (Michaud, 2019; Fig. 9). Type I and II veins possess the strongest magmatic imprint. Type I veins have a coarse internal texture close to a pegmatite (Fig. $4 \mathrm{~b}$ ) and a granitic mineralogical composition (presence of abundant alkali feldspars). They lack alteration aureoles at vein margins (this is also the case for the Type II and III veins) indicating chemical equilibrium with the host granite. It is worth stressing that neither cassiterite nor columbite-tantalite is deposited in Type I and II veins which contain only montebrasite mineralization (Fig. $4 \mathrm{~b}, \mathrm{c})$. The mineralogical data demonstrate progressive dilution of the magmatic signature from Type I and II to Type III veins. Type III wolframite-bearing veins still contain some alkali feldspars. However, veins with a larger amount of wolframite are alkali feldspar-free and cassiterite (Cst III) is Nb- and Ta-poor and Fe-rich compared to Cst I-II. Such cassiterite geochemical signatures are interpreted as typically hydrothermal (Tindle and Breaks 1998; Breiter et al. 2007). Cst III shows an extensive replacement by stannite which indicates the influx of external sulfur-bearing fluids in the intragranitic hydrothermal system (Michaud, 2019). CT III inclusions in wolframites are also more Fe-rich than disseminated columbite-tantalite (Fig. 8). Finally, some Type III and the Santa Rita vein, located near the E contact with the country rocks and close to the dextral shear, record an evolution toward texturally late, more Fe-rich wolframite compositions.

Mineralization in country rock veins is interpreted as the extension to their respective aureoles of hydrothermal systems originated within the granites. This type of mineralization is particularly well represented in the AM system, including montebrasite and, in some cases, cassiterite, but lacking columbite-tantalite and wolframite (Fig. 9). The large number of veins together with their size is the mark of a large hydrothermal system genetically related to a hidden granitic apophyse (Inverno and Ribeiro, 1980 and see above, 6.1). In the CA system, the only recognized country rock vein contains wolframite but no cassiterite (Fig. 9). We remind here that early wolframites are hubneriteswhile late wolframites are ferberites (Michaud and Pichavant, 2019). The latter compositions contrast with intragranitic veins but are well in the range of country rock veins nearby (Panasqueira, Neiva 2008). At Panasqueira, wolframite deposition involves fluid components coming from the country rocks (Lecumberri-Sanchez et al., 2017). At Argemela, the presence of a late sulphide stage in both country rock and intragranitic veins points to a non-magmatic component being involved. In the AM, granite in the drill core is intersected by sulphide-bearing veinlets, and sulphides crystallize as stannite in veins, replacing cassiterite. In the CA, sulphides are restricted to the eastern border of the granite which is affected by the $\mathrm{N} 170-175^{\circ} \mathrm{E}$ dextral shear corridor. They are found in Type III veins as late arsenopyrite and vivianite and as disseminated crystals mostly around Type III veins in the granite.

\subsection{Contrasted behavior of Sn and $W$}

The AMA provides a remarkable illustration of the contrasted behavior of $\mathrm{Sn}$ and $\mathrm{W}$ in granite-related mineralization (Fig. 9; 11). In 
the RMGs, disseminated cassiterite, typically enriched in $\mathrm{Nb}$ and $\mathrm{Ta}$ when compared to hydrothermal cassiterite (Fig. 7a; Tindle and Breaks 1998; Breiter et al. 2007; Neiva, 2008), crystallizes as a magmatic phase (see above, 6.3, Fig. 9). Whole-rock Sn concentrations are in the range of Variscan tin-rich granites (Cuney et al. 1992; Raimbault et al. 1995; Charoy and Noronha 1996; Table 1). Micas from the Argemela granite are also Sn-rich (Charoy et al., 1995; Michaud, 2019) suggesting early tin enrichment. Such whole-rock concentrations are in the range of the solubility of cassiterite determined under appropriate $\mathrm{fO}_{2}$ and temperature (Linnen and Cuney, 2005) thus indicating cassiterite saturation in AM and CA RMG melts. Compositions of certain volcanic rocks (e.g., Macusani glasses, Pichavant et al., 1987; Richemont rhyolite, Raimbault and Burnol, 1998) and silicate inclusions (e.g., Ehrenfriedersdorf inclusions, Webster et al., 1997; Rickers et al., 2006) confirm that Sn enrichment in RMG-like melts is the result of magmatic processes. The AMA thus provides a clear case for $\mathrm{Sn}$ being concentrated and deposited at the magmatic stage.

In contrast, for $\mathrm{W}$, no magmatic mineral carrier has been identified in the RMGs. Wolframite is absent as a magmatic phase (Fig. 9) and the possibility of magmatic wolframite is currently debated (Che et al. 2013 and references therein). Whole-rock W concentrations in the RMGs (Charoy and Noronha 1996; Table 1) are generally much less than experimental wolframite solubilities although wolframite saturation might be approached if granite crystallization takes place at $<600^{\circ} \mathrm{C}$ (Che et al. 2013). These data consistently suggest that the AMA RMGs did not reach wolframite saturation, at the difference of cassiterite for Sn. However, this does not rule out the possibility of $\mathrm{W}$ being concentrated at the magmatic stage. Evidence for $\mathrm{W}$ concentration in RMG-like melts is provided by the Macusani glasses (Pichavant et al., 1987), the Richemont rhyolite (Raimbault and Burnol 1998) and the Ehrenfriedersdorf inclusions (Rickers et al. 2006). Although the available data on the AMA provides no constraint on the RMG melt $\mathrm{W}$ concentrations, the mode of wolframite deposition strongly suggests a magmatic source for $\mathrm{W}$, as for $\mathrm{Sn}$.

The occurrence of wolframite in Type III intragranitic veins constitutes the earliest mineralogical expression of $\mathrm{W}$ in the AMA ore-forming sequence (Fig. 9). These wolframite-bearing veins, chronologically the latest among intragranitic veins, are characterized by ore mineral assemblages and compositions (see above, 4,5 ) indicating no significant influence of external fluids derived from country rocks. It is recalled that the intragranitic veins are at equilibrium with the granite and, so, wolframite deposition in Type III veins strongly suggests supply of W by fluids exsolved from the granite at the magmatic-hydrothermal transition (Michaud, 2019).

This mode of $\mathrm{W}$ mineralization markedly differs from what is observed in most Variscan deposits. For example, at Logrosán (Chicharro et al. 2016) and Panasqueira (Neiva 2008; Lecumberri-Sanchez et al., 2017), wolframite is exclusively deposited from hydrothermal systems with only indirect link with magmatic activity. At Cligga Head (Smith et al. 1996), there is a clear spatial relationship with the magmatic system but the intragranitic wolframite-bearing veins are fringed by alteration zones at their margins suggesting disequilibrium between the mineralizing fluids and the host granite. This stresses the specificity of the early wolframite deposition stage in the AMA where a clear link with granite crystallization and fluid exsolution is evidenced. This difference between the AMA on the one hand and most Variscan deposits on the other hand is also marked in wolframite compositions, overall more Mn-rich in the AMA than in other Variscan deposits (Michaud and Pichavant, 2019).

Despite evidence for early deposition by magmatic fluids, wolframite is in general relatively rare in the AMA. In addition to the Type III veins, wolframite only occurs in one CA and is totally absent from the AM country rock veins. No large $\mathrm{W}$ vein system (such as found nearby at Panasqueira, Kelly and Rye 1979; Neiva 2008; Lecumberri-Sanchez et al., 2017) has been recognized in the AMA. Rare element minerals deposited in significant amounts from hydrothermal systems in the AMA only include cassiterite and montebrasite as demonstrated by the AM vein swarm since the CA intragranitic and country rock veins are cassiterite-poor. Cassiterite is absent in Type I and II veins and minor cassiterite is deposited together with wolframite in Type III veins. This near absence of cassiterite is attributed to physicochemical conditions favoring $\mathrm{Sn}$ transport rather than deposition in the CA intragranitic hydrothermal system. Therefore, the mode of expression of $\mathrm{Sn}$ is essentially magmatic in the CA and both magmatic and hydrothermal in the AM. This difference most probably indicates a contrasted behavior of $\mathrm{Sn}$ at the hydrothermal stage since $\mathrm{Sn}$ is enriched in granitic rocks from both systems (Table 1). Sn might have been transferred more efficiently from the hidden granite apophyse than from the Argemela granite which would be consistent with lower $\mathrm{Sn}$ in granitic dykes than in the Argemela RMG (Table 1). The amount of fluids and size of respective hydrothermal systems could also have played a role. The AM vein swarm suggests that the fluid flux was much larger (and the hydrothermal system possibly longer-lived) in the AM than in the CA, which could have promoted the extraction of Sn from the AM granitic source.

To summarize, the AMA demonstrates a strong contrast between Sn and $\mathrm{W}$ at the magmatic and magmatic-hydrothermal stages. Both Sn and $\mathrm{W}$ have a magmatic source but only $\mathrm{Sn}$ reaches concentrations leading to saturation of the melt with cassiterite (and also columbite-tantalite). Although Sn and W were presumably both transferred toward the magmatic fluid phase, $\mathrm{W}$ deposition occurred preferentially to $\mathrm{Sn}$ in intragranitic veins. At the hydrothermal stage, cassiterite and wolframite deposition are disconnected (being exclusive from each other in the AM and CA country rock vein systems) and, overall, wolframite occurs only in minor amounts. This stresses the importance of physical and chemical factors controlling rare metal deposition vs. transport at the hydrothermal stage.

\subsection{Metallogenic model}

Fig. 11 illustrates the mineralized components and the integrated metallogenic evolution proposed for the AMA. At depth, the area is underlain by a magmatic body of presumably batholitic size according to the local geological constraints (Charoy and Noronha, 1996). This composite body is the product of assembly of multiple magmatic intrusions emplaced at different structural levels, some as granitic apophyses and others as shallower stocks. Two of such apophyses, one in the $\mathrm{AM}$ and one in the CA (to account for the wolframite-bearing country rock vein, see 6.1) are shown (Fig. 11). Similarly, the two AM and CA RMGs are depicted as small late subvolcanic intrusions. These different magmatic components are not cogenetic, but they share a similar rare metal enriched geochemical signature. Magmatic processes lead to metal incorporation and enrichment (Fig. 11a). Saturation thresholds for rare metal phases are eventually overstepped and cassiterite, columbite-tantalite and montebrasite (this phase only in the Argemela RMG) crystallize as disseminated minerals within the granites. Further crystallization leads to the building-up of volatiles in the residual melt and to the exsolution of magmatic fluids. These fuel the emplacement of the intragranitic vein systems in the two RMGs (Fig. 11b). Metals partitioned into the magmatic fluid are transported and undergo selective deposition processes, illustrated by the crystallization of wolframite with only subordinate cassiterite in the CA Type III intragranitic veins. Due to limited pressure at shallow levels and thermal effect (i.e. small stocks), the magmatic fluid exsolved from rare metal magmas stay confined within the intrusion inhibiting interaction with the host rock and the development of large hydrothermal systems. Consequently, mineralization mainly occurs as disseminated minerals. This 


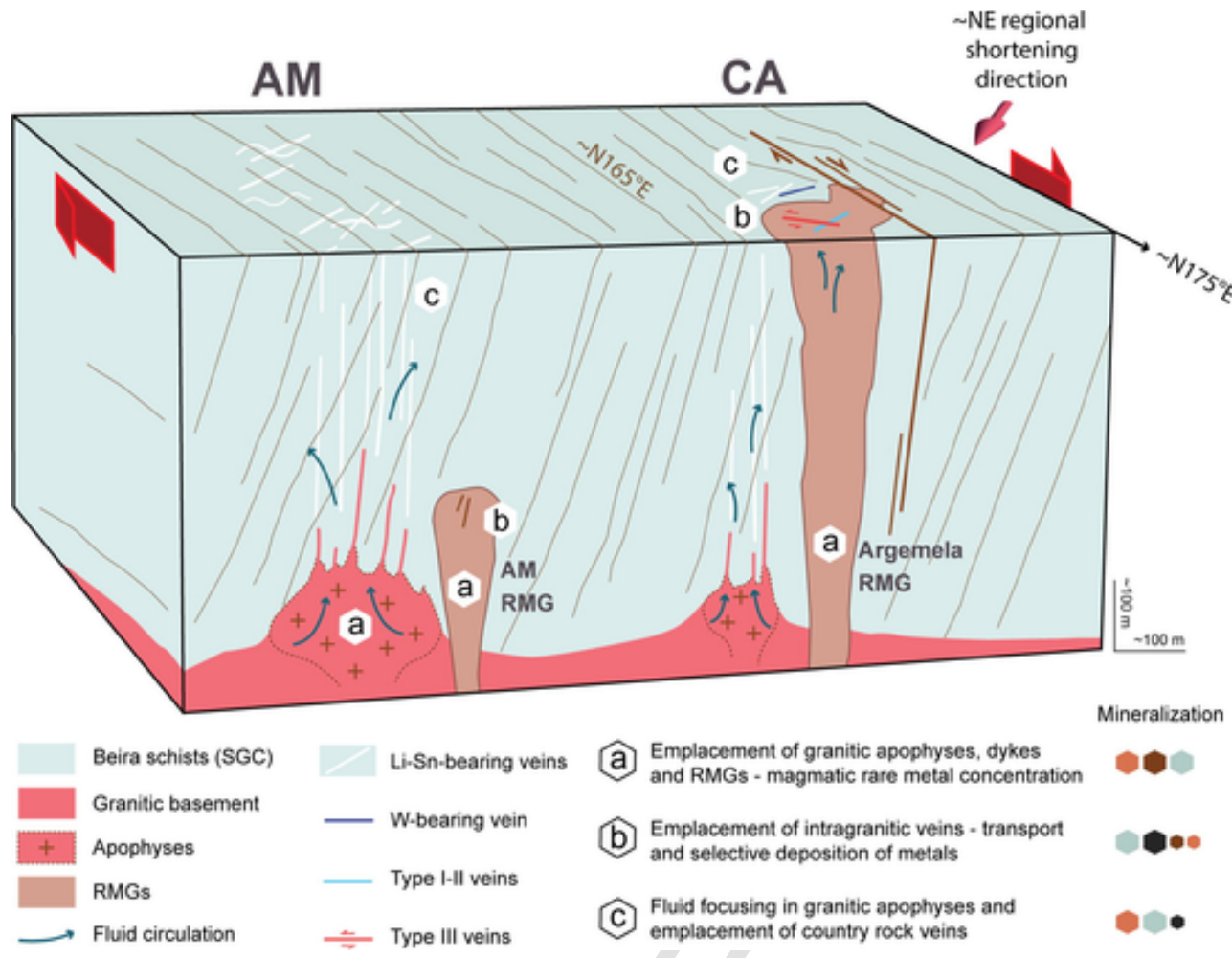

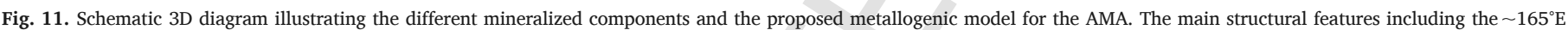

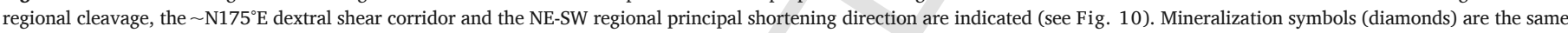

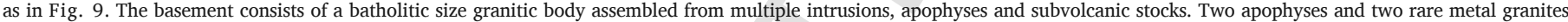

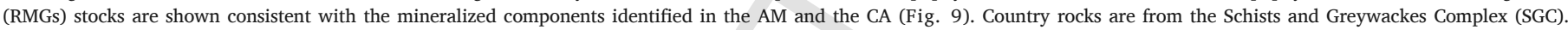

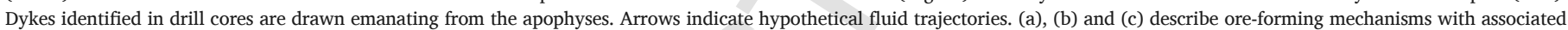
mineralization. See text for additional details and explanations.

is to be compared to the Beauvoir rare metal system (e.g. Raimbault et al., 1995) where mineralization only happen as disseminated. Conversely, at Cínovec, evolved units underwent intense hydrothermal alteration allowing leaching of elements from primary magmatic phases and their redistribution/concentration in greisen and veins forming a significant ore deposit (e.g. Breiter et al., 2017). At deeper levels, greater pressure will result in fluid overpressure promoting fracturing and interactions of the magmatic fluid with the surrounding rocks. Significant thermal effects on adjacent country rocks are also expected because magma bodies are larger, favoring the development of larger hydrothermal systems. This accounts for the focusing of large amounts of fluids in granitic apophyses and for the extension of hydrothermal systems to the country rocks as represented by the AM vein swarm (Inverno and Ribeiro, 1980 and see above, 6.1, Fig. 11c). Metal transport and mineral (cassiterite, montebrasite) deposition processes in country rock veins reflect the origin and composition of the fluid and possibly additional controlling factors such as wall-rock interactions. The model emphasizes the difference in origin between the two vein systems, intragranitic in the CA and country rock in the AM. However, both were emplaced in the same structural context and tectonic regime (see above, 6.2) and they can be viewed as two variants of the same type of Sn-Li-(Nb-Ta)-dominated and W-poor metallogenic system. This model also illustrates how the tectonic regime, the rheology of host rocks and the size of the granitic system will influence the mode of expression and the distribution of mineralization.

\section{Conclusions}

Detailed field, structural and mineralogical data on the AMA have been integrated and a metallogenic model developed for this representative Variscan granite-related rare metal mineralized area. The key points of this study are as follows:

- The AMA comprises two spatially close mineralized systems (the AM and the CA) which share similarities but also show first-order differences and overall provide complementary information on the local metallogenic evolution.

- Three mineralizing episodes are distinguished: (1) disseminated $\mathrm{Sn}$-Nb-Ta-Li mineralization in rare metal granites, (2) (Sn)-W-Nb-Ta-Li mineralization in intragranitic veins and (3) $\mathrm{Sn}$-(W)-Li mineralization in country rock veins. These episodes are correlated with systematic changes in major element compositions of cassiterite, columbite-tantalite, wolframite and montebrasite.

- The three episodes define a metallogenic evolution initiated at the magmatic stage, pursued during the magmatic-hydrothermal transition and ended with hydrothermal circulations in country rocks. The AMA provides a rare case of a nearly continuous closely spatially associated magmatic to hydrothermal mineralizing sequence.

- The tectonic regime and host rock mechanical properties have a key importance in the distribution and expression of mineralization (i.e. disseminated vs veins). The intragranitic veins and the country rock veins in the AMA developed in the same structural context and, so, both are part of the same local metallogenic evolution.

- Sn and W were both enriched during the magmatic evolution and transferred together into the magmatic fluid phase. Yet, only cassiterite saturation in the magmas is observed. Wolframite deposition is early and takes place preferentially to cassiterite during the magmatic-hydrothermal stage. At the hydrothermal stage, cassiterite and wolframite deposition are spatially disconnected and, overall, wolframite is present only in minor amounts. 
- The metallogenic model proposed identifies rare metal concentration at the magmatic stage, magmatic fluid exsolution, transfer and selective deposition of metals during the magmatic-hydrothermal and later hydrothermal stages as key steps. Overall, magmatic processes are emphasized. Fluid-rock interaction processes such as greisenization are not prominent in the AMA.

- The AMA has a Li-Sn-(Nb-Ta)-dominated and W-poor signature close to LCT pegmatites in the Central Iberian Zone (e.g., Roda-Robles et al., 2016) and is distinctive from the world class $\mathrm{W}$-(Sn-Cu) Panasqueira deposit nearby (e.g., Lecumberri-Sanchez et al., 2017) and most other $W$ deposits from the French Massif Central (e.g., Harlaux et al., 2018).

\section{Uncited references}

\section{Acknowledgements}

The authors acknowledge A. Lima, F. Noronha, F. Pinto and R. Ribeiro for their support in the field and for discussions; P. Moutela and P. Ferraz for giving access to the Argemela quarry and the mine. I. Di Carlo is acknowledged for assistance with the electron microprobe analyses. This work was supported by the Labex VOLTAIRE (ANR-10-LABX-100-01), ERAMIN project NewOres and the ANR project VARPEG (ANR-15-CE01-0001). This manuscript has benefited from the constructive reviews from Pr. Breiter, an anonymous reviewer and the Editor-in-Chief Pr. Chen.

\section{References}

Ábalos, B., Carreras, J., Druguet, E., Escuder Viruete, J., Gómez Pugnaire, M.T., Alvarez, S.L., Quesada, C., Rodríguez Fernández, L.R., Gil-Ibarguchi, J.I., 2002. Variscan and Pre-Variscan tectonics. The Geology of Spain, Gibbons W, Moreno T, pp. 155-183.

Aubert, G., 1969. Les coupoles granitiques de Montebras et d'Échassières:(Massif Central français) et la genèse de leurs minéralisations en étain, lithium, tungstène et béryllium. Éditions BRGM.

Autran, A., Cogné, J., 1980. La zone interne de l'orogène varisque dans l'Ouest de la France et sa place dans le développement de la chaîne hercynienne. Mémoires du BRGM 1, 191-202.

Bard, J.P., Burg, J.P., Matte, P., Ribeiro, A., 1980. La chaine hercynienne d'Europe occidentale en termes de tectonique des plaques. Géologie de l'Europe 108, 233-246.

Béziat, P., Prouhet, J.P., Tollon, F., 1980. Le district de Montredon-Labessonnié (Tarn), 26 Congres International de Géologie E7.

Bons, P.D., Elburg, M.A., Gomez-Rivas, E., 2012. A review of the formation of tectonic veins and their microstructures. J. Struct. Geol. 43, 33-62.

Breiter, K., Škoda, R., Uher, P., 2007. Nb-Ta-Ti-W-Sn-oxide minerals as indicators of a peraluminous P- and F-rich granitic system evolution: Podlesí, Czech Republic. Mineral. Petrol. 91, 225-248.

Breiter, K., Ďurišová, J., Hrstka, T., Korbelová, Z., Hložková Vaňková, M., Vašinová Galiová, M., Kanický, V., Rambousek, P., Knésl, I., Dobeš, P., Dosbaba, M., 2017. Assessment of magmatic vs metasomatic processes in rare-metal granites: a case study of the Cínovec/Zinnwald Sn-W-Li deposit, Central Europe. Lithos 292-293, 198-217.

Cameron, J., 1951. The geology of Hemerdon wolfram mine, Devon. Transactions of the Institute of Mining and Metallurgy 61, 1-14.

Černý, P., Roberts, W.L., Ercit, T.S., Chapman, R., 1985. Wodginite and associated oxide minerals from the Perless pegmatite, Pennington County, South Dakota. Am. Mineral. 70, 1044-1049.

Černý, P., Blevin, P.L., Cuney, M., London, D., 2005. Granite-related ore deposits. Econ. Geol. 100, 337-370.

Charoy, B., Chaussidon, M., Noronha, F., 1995. Lithium zonation in white micas from the Argemela microgranite (central Portugal): an in-situ ion-, electron-microprobe and spectroscopic investigation. European Journal of Mineralogy 7, 335-352.

Charoy, B., Noronha, F., 1996. Multistage growth of a rare-element, volatile-rich microgranite at Argemela (Portugal). J. Petrol. 37, 73-94.

Charoy, B., Noronha, F., 1999. Rare-element (Li-rich) granitic and pegmatitic plutons: a primary or superimposed signature? Revista Brasileira de Geociências 29, 3-8.

Che, X.D., Linnen, R.L., Wang, R.C., et al., 2013. Tungsten solubility in evolved granitic melts: an evaluation of magmatic wolframite. Geochim. Cosmochim. Acta 106, 84-98.

Chicharro, E., Boiron, M.-C., López-García, J., et al., 2016. Origin, ore forming fluid evolution and timing of the Logrosán Sn-(W) ore deposits (Central Iberian Zone, Spain). Ore Geol. Rev. 72, 896-913.
Cuney, M., Friedrich, M., Blumenfeld, P., et al., 1990. Metallogenesis in the French part of the Variscan orogen. Part I: U preconcentrations in pre-Variscan and Variscan formations - a comparison with Sn, W and Au. Tectonophysics 177, 39-57.

Cuney, M., Marignac, C., Weisbrod, A., 1992. The Beauvoir topaz-lepidolite albite granite (Massif Central, France); the disseminated magmatic Sn-Li-Ta-Nb-Be mineralization. Econ. Geol. 87, 1766-1794.

Cuney, M., Alexandrov, P., Carlier, L., de Veslud, C., Cheilletz, A., Raimbault, L., Ruffet, G., Scaillet, S., 2002. The timing of W-Sn-rare metals mineral deposit formation in the Western Variscan chain in their orogenic setting: the case of the Limousin area (Massif Central, France). Geological Society of London, Special Publications 204, 213-228.

Cuney, M., Barbey, P., 2014. Uranium, rare metals, and granulite-facies metamorphism. Geosciences Frontiers 1-17.

Demange, M., Nicolas, V.A., Soler, P., Giouse, H., 1988. Le gisement tungstifère de Leucamp (Cantal, France): contrôle géologiques et minéralisations. Bulletin de la Société Géologique de France 4, 559-570.

Dias, R., Ribeiro, A., 1995. The Ibero-Armorican arc: a collisional effect against an irregular continent? Tectonophysics 246, 113-128.

Díez Balda, M.A., Vegas, R., González Lodeiro, F., 1990. Central Iberian Zone: autochthonous sequences. Pre-Mesozoic Geology of Iberia, Dallmeyer RD, Martínez García $171-188$.

Faure, M., 1995. Late orogenic carboniferous extensions in the Variscan French Massif Central. Tectonics 14, 132-153.

Faure, M., Leloix, C., Roig, J.Y., 1997. L'évolution polycyclique de la chaîne hercynienne. Bulletin de la Société Géologique de France 168 (6), 695-705.

Ferreira, M.P., Macedo, C.R., Alves, E.I., 1985. A zonalidade interna de um plutonito. Estruturas condicionantes e idades de evoluçào (Plutonio do Fundão, Portugal Central). Memorias e Noticias Publicadas pelo Musell do Laboratorio de Mineralogia e Geologia da Universidade de Coimbra 99, 167-186.

Harlaux, M., Marignac, C., Cuney, M., Mercadier, J., 2015. Nb-Ti-Y-HREE-W-U oxide minerals with uncommon compositions associated with the tungsten mineralization in the Puy-Les-Vignes deposit (Massif Central, France): evidence for rare-metal mobilization by late hydrothermal fluids with a peralkaline signature. The Canadian Mineralogist $53,653-672$.

Harlaux, M., Romer, R., Mercadier, J., Morlot, C., Marignac, C., Cuney, M., 2017. 40 Ma of hydrothermal W mineralization during the Variscan orogenic evolution of the French Massif Central revealed by U-Pb dating of wolframite. Miner. Deposita 1-31.

Harlaux, M., Mercadier, J., Marignac, C., Peiffert, C., Cloquet, C., Cuney, M., 2018. Tracing metal sources in peribatholitic hydrothermal $\mathrm{W}$ deposits based on the chemical composition of wolframite: the example of the Variscan French Massif Central. Chemical Geology.

Heinrich, C.A., 1990. The chemistry of hydrothermal tin (-tungsten) ore deposition. Econ. Geol. 85, 457-481.

Inverno, C., Ribeiro, M.L., 1980. Fracturação e cortejo filoneano nas Minas da Argemela (Fundão). Commission Serviços Geológicos de Portugal 66, 185-193.

Inverno, C., 1998. Comments on the new findings on the geology, geochemistry and mineralization of Argemela, central Portugal. Commission Instituto Geológico e Mineiro 85, 73-79.

Kelly, W.C., Rye, R.O., 1979. Geologic, fluid inclusion, and stable isotope studies of the tin-tungsten deposits of Panasqueira, Portugal. Econ. Geol. 74, 1721-1822.

Korges, M., Weis, P., Lüders, V., Laurent, O., 2018. Depressurization and boiling of a sin gle magmatic fluid as a mechanism for tin-tungsten deposit formation. Geology 46, 75-78.

LeBoutillier, N.G., 2002. The tectonics of Variscan magmatism and mineralisation in South West England. Thesis, University of Exeter.

Lecumberri-Sanchez, P., Vieira, R., Heinrich, C.A., Pinto, F., Wälle, M., 2017. Fluid-rock interaction is decisive for the formation of tungsten deposits. Geology 45, 579-582.

Lehmann, B., 1990. Metallogeny of Tin. 211 pp. Springer.

Lerouge, C., Bouchot, V., Guerrot, C., 2000. Fluids and the W ( \pm As, Au) ore deposits of the Enguialès-Leucamp District, La Châtaigneraie, French Massif Central. J. Geochem. Explor. 69, 343-347.

Linnen RL, Cuney M (2005) Granite-related rare-element deposits and experimental constraints on Ta-Nb-W-Sn-Zr-Hf mineralization, in Linnen RL and Samson IM, eds. rare-element geochemistry and mineral deposits. In: Geological Association of Canada, GAC, Short Course Notes 17, 45-68

Llorens, T., Moro, M.C., 2012a. Oxide minerals in the granitic cupola of the Jálama Batholith, Salamanca, Spain. Part I: accessory Sn, Nb, Ta and Ti minerals in leucogranites, aplites and pegmatites. J. Geosci. 57, 25.

Llorens, T., Moro, M.C., 2012b. Oxide minerals in the granitic cupola of the Jálama Batholith, Salamanca, Spain. Part II: Sn, W and Ti minerals in intra-granitic quartz veins. J. Geosci. 57, 155.

London, D., Morgan, G.V.I., Wolf, M.B., 2001. Amblygonite-montebrasite solid solutions as monitors of fluorine in evolved granitic and pegmatitic melts. Am. Mineral. 86, 225-233.

Marignac, C., Cuney, M., 1999. Ore deposits of the French Massif Central: insight into the metallogenesis of the Variscan collision belt. Miner. Deposita 34, 472-504.

Marignac, C., Cathelineau, M., 2009. The nature of ore-forming fluids in peri-batholitic Sn-W deposits and a classification. In: Smart science for exploration and mining, Proceedings Xth Biennial SGA Meeting, Townsville 245-247

Martínez Poyatos, D., Nieto, F., Azor, A., Simancas, J.F., 2001. Relationships between very low-grade metamorphism and tectonic deformation: examples from the southern Central Iberian Zone (Iberian Massif, Variscan Belt). Journal of the Geological Society 158, 953-968. doi:10.1144/0016-764900-206.

Matte, P., 1986. Tectonics and plate tectonics model for the Variscan belt of Europe Tectonophysics 126, 329-374. 
Melleton, J., Gloaguen, E., Frei, D., 2015. Rare elements (Li-Be-Ta-Sn-Nb) magmatism in the European Variscan belt, a review. Mineral Resources in a Sustainable World. 13th SGA Biennial Meeting, Proceedings 2, 807-810.

Michaud, J.A.-S., Pichavant, M., 2019. The H/F ratio as an indicator of contrasted wolframite deposition mechanisms. Ore Geol. Rev. 104, 266-272. doi:10.1016/ j.oregeorev.2018.10.015.

Michaud, J.A.-S., 2019. Rare metal granites: origin, emplacement and mechanisms of the magmatic hydrothermal transition. Insights from the Argemela rare metal granite (Portugal) and an experimental study PhD thesis. University of Orléans, p. 365.

Müller, A., Seltmann, R., 1999. The genetic significance of snowball quartz in high fractionated tin granites of the Krušne Hory/Erzgebirge. Mineral deposits: processes to processing 1, 409-412.

Neiva, A.M.R., 1996. Geochemistry of cassiterite and its inclusions and exsolution products from tin and tungsten deposits in Portugal. The Canadian Mineralogist 34, 745-768.

Neiva, A.M.R., 2008. Geochemistry of cassiterite and wolframite from tin and tungsten quartz veins in Portugal. Ore Geol. Rev. 33, 221-238.

Noronha F, Ribeiro M A, Almeida A, Dória A, Guedes A, Lima A, Martins H C, Sant'Ovaia H, Nogueira P, Martins T, Ramos R, Vieira R (2013) Jazigos filonianos hidrotermais e aplitopegmatíticos espacialmente associados a granitos (Norte Portugal). In: Geologia de Portugal Vol. I, Geologia Pré-Mesozoica de Portugal (Eds) Dias R, Araùjo A, Terrinha P, Kulberg J C C K, Escolar E Editora

Olivier, P., Améglio, L., 2002. Structure et mise en régime décrochant puis rotation tardi-magmatique des plutons granitiques hercyniens du Veinazès et de Marcolès (Châtaigneraie, Massif Central Français). Bulletin de la Société Géologique de France 173, 207-218.

Pereira, E., Ribeiro, A., Meireles, C., 1993. Cisalhamentos hercínicos et control das mineralizações de Sn-W, Au e U na zona Centro-Ibérica, em Portugal. Cuaderno Lab. Xeolóxico de Laxe 18, 89-119.

Pichavant, M., Valencia Herrera, J., Boulmier, S., Briqueu, L., Joron, J.-L., Juteau, M., Marin, L., Michard, A., Sheppard, S.M.F., Treuil, M., Vernet, M., 1987. The Macusani glasses, SE Peru: evidence of chemical fractionation in peraluminous magmas. In: Mysen BO (ed) Magmatic processes, physicochemical principles. The Geochemical Society, Special Publication No.1.

Raimbault, L., Burnol, L., 1998. The Richemont rhyolite dyke, Massif Central, France: a subvolcanic equivalent of rare-metal granites. The Canadian Mineralogist 36, 265-282.

Raimbault, L., Cuney, M., Azencott, C., Duthou, J.L., Joron, J.L., 1995. Geochemical evidence for a multistage magmatic genesis of Ta-Sn-Li mineralization in the granite at Beauvoir, French Massif Central. Econ. Geol. 90, 548-576.

Ribeiro, A., Kullberg, M.C., Kullberg, J.C., Manuppella, G., Phipps, S., 1990b. A review of Alpine tectonics in Portugal: Foreland detachment in basement and cover rocks. Tectonophysics, Alpine Evolution of Iberia and its Continental Margin 184, 357-366.

Ribeiro, A., Pereira, E., Dias, R., 1990a. Central Iberian Zone. Allochthonous sequences. Structure in the Northwest of the Iberian Peninsula. In: Dallmeyer, R.D., Martinez
Garcia, E. (Eds.), Pre-Mesozoic Geology of Iberia. Springer-Verlag, Berlin, Heidelberg, pp. $220-236$.

Rickers, K., Thomas, R., Heinrich, W., 2006. The behavior of trace elements during the chemical evolution of the $\mathrm{H}_{2} \mathrm{O}-$, B-, and F-rich granite-pegmatite-hydrothermal system at Ehrenfriedersdorf, Germany: a SXRF study of melt and fluid inclusions. Miner. Deposita 41, 229-245.

Roda-Robles, E., Pesquera, A., Gil-Crespo, P.P., Viera, R., Lima, A., Garate-Olave, I., Martins, T., Torres-Ruiz, J., 2016. Geology and mineralogy of Li mineralization in the Central Iberian Zone (Spain and Portugal). Mineral. Mag. 80, 103-126.

Romer, R.L., Kroner, U., 2016. Phanerozoic tin and tungsten mineralization-tectonic controls on the distribution of enriched protoliths and heat sources for crustal melting. Gondwana Res. 31, 60-95.

Scaillet, S., Cheilletz, A., Cuney, M., Farrar, E., Archibald, D.A., 1996a. Cooling pattern and mineralization history of the Saint-Sylvestre and western Marche leucogranite pluton, French Massif Central: I. ${ }^{40} \mathrm{Ar} /{ }^{39} \mathrm{Ar}$ isotopic constraints. Geochim. Cosmochim. Acta 60, 4653-4671.

Scaillet, S., Cuney, M., Carlier, L, de Veslud, C., Cheilletz, A, Royer, J.J., 1996b, Cooling pattern and mineralization history of the Saint-Sylvestre and western Marche leucogranite pluton, French Massif Central: II. Thermal modelling and implications for the mechanisms of uranium mineralization. Geochim. Cosmochim. Acta 60, 4673-4688.

Smith, M., Banks, D.A., Yardley, B.W., Boyce, A., 1996. Fluid inclusion and stable isotope constraints on the genesis of the Cligga Head Sn-W deposit, SW England. Eur. J. Mineral. 8, 961-974.

Štemprok, M., Seltmann, R., Breiter, K., 1995. The Cínovec/Zinnwald Sn-W-Li deposit. Ore mineralization of the Krušné hory Mts (Erzgebirge). Excursion Guide, Prague, Czech Geological Survey, pp. 77-83.

Štemprok, M., Blecha, V., 2015. Variscan Sn-W-Mo metallogeny in the gravity picture of the Krušné hory/Erzgebirge granite batholith (Central Europe). Ore Geol. Rev. 69, 285-300.

Suwinonprecha, M.N., Černý, P., Friedrich, G., 1995. Rare metal mineralization related to granites and pegmatites, Phuket, Thailand. Econ. Geol. 90, 603-615.

Taylor, R.G., Hosking, K.F.G., 1970. Manganese-Iron ratios in wolframite, South Crofty Mine, Cornwall. Econ. Geol. 65, 47-53.

Tindle, A.G., Breaks, F.W., 1998. Oxide minerals of the separation rapids rare-element granitic pegmatite group, Northwestern Ontario. The Canadian Mineralogist 36, 609-635.

Tornos, F., Galindo, C., Crespo, J.L., Spiro, B.F., 2008. Geochemistry and origin of calcic tungsten-bearing skarns, Los Santos, Central Iberian Zone, Spain. The Canadian Mineralogist 46, 87-109.

Consultores, V., 2017. Estudo de impacte Ambiental Mina Da Argemela. Report.

Webster, J.D., Thomas, R., Rhede, D., et al., 1997. Melt inclusions in quartz from an evolved peraluminous pegmatite: Geochemical evidence for strong tin enrichment in fluorine-rich and phosphorus-rich residual liquids. Geochim. Cosmochim. Acta 61, 2589-2604. 